\title{
Udržitelné podnikání na venkově - inspirace pro vzdělání
}

\author{
Jana Dlouhá \\ Envigogika 12 (1) - Inspirace / Inspiration
}

Publikováno/Published dne 23. 07. 2017

DOI: $\underline{10.14712 / 18023061.544}$

\begin{abstract}
Abstrakt
Žijeme ve světě, který trpí četnými problémy - většinou takovými, které jsme sami způsobili svou sobeckostí, pohodlností, snahou získat nezasloužené výhody na úkor někoho (nebo něčeho) jiného. Vzdělávání se ale nemusí přísně držet světa, jaký je; jeho prostřednictvím Ize usilovat o svět, jaký by měl být. Na rozdíl od vědy se vzdělávací cíle mohou vztahovat nejen $\mathrm{k}$ realitě, ale také $\mathrm{k}$ ideálu. Na tomto ideálním půdorysu lze pak utvářet nové vztahy, pěstovat podstatné zásady, a postupně tak založit jinou, lepší společnost. Svého humanistického poslání si je vzdělání vědomo - právě zde jsou úspěšně rozvíjeny idealistické vize, sem se soustřed'uji snahy sociálních reformátorů, kteří prosazují dlouhodobou představu "trvale udržitelné" společnosti a nehledí jen na společenský vzestup podle pravidel okamžité úspěšnosti. Vzdělání tak usiluje o společnost, která by se zabývala "vážnými" problémy, a chtěla je řešit s ohledem na každého jednotlivce, jenž by se pak cítil $\checkmark$ jejím rámci svobodně a také užitečně - byl by oporou svému společenství právě tak, jako toto společenství poskytuje bezpečné zázemí jemu samému. Taková společnost by měla být založena nejen na rozumné a efektivní správě, která reguluje konkurenční prostředí. Měla by vycházet z ekonomiky, která se vrací k původnímu smyslu tohoto slova - péči o domov (oikos) - a vytváŕí tak základní hodnoty, pečuje o ně v dlouhodobém časovém horizontu. Bez tohoto základu postrádá kolektivní lidské snažení smysl. A bez "autentického" vztahu k původním zdrojům, postupům, procesům a jejich výsledkům zase tyto základní hodnoty nemohou vznikat. Abychom tento bezprostřední vztah ke skutečnosti, který se potvrzuje prací, neztratili, je třeba $\mathrm{k}$ jeho zachování přizvat i vzdělávací systém. Tato publikace má být malým př́spěvkem do debaty na toto téma.
\end{abstract}

\section{Klíčová slova}

Udržitelný rozvoj; kompetence; drobné podnikání; venkov

\begin{abstract}
Unlike science, educational goals can relate not only to reality but also to the ideal. Education is thus in the centre of attention of social reformers who enforce long-term vision of a "sustainable" society that does not associate its development just with immediate success. Such a society should be based on an economy that reveals the original meaning of this word - care for home (oikos) - creating thus basic values, and caring for them over the long term. These core values cannot arise without an "authentic" relationship with the original resources, techniques, processes and their results. In order to preserve these direct
\end{abstract}


relationships, re-established through the work, the education system must also be invoked. The presented publication is a small contribution to the debate on this subject - it shows the work as a culture-forming element, while this role is recently jeopardized. However, thorough, creative work is important for individuals and for society: needed to reflect intrinsic motivation, one's place in the wider community and in the surrounding environment; helping to build relationships with other people and to uncover sense of everyday existence. In order to be able to perform such a meaningful and useful job, many competencies are needed, which are described in this publication by the small entrepreneurs. The authors recorded their words in categories that emerged from the subsequent qualitative analysis of these interviews - this experience is thus presented to be used in "practice" of teaching.

\section{Keywords}

Sustainable development; competences; rural entrepreneurs 


\section{Udržitelné podnikání na venkově -}

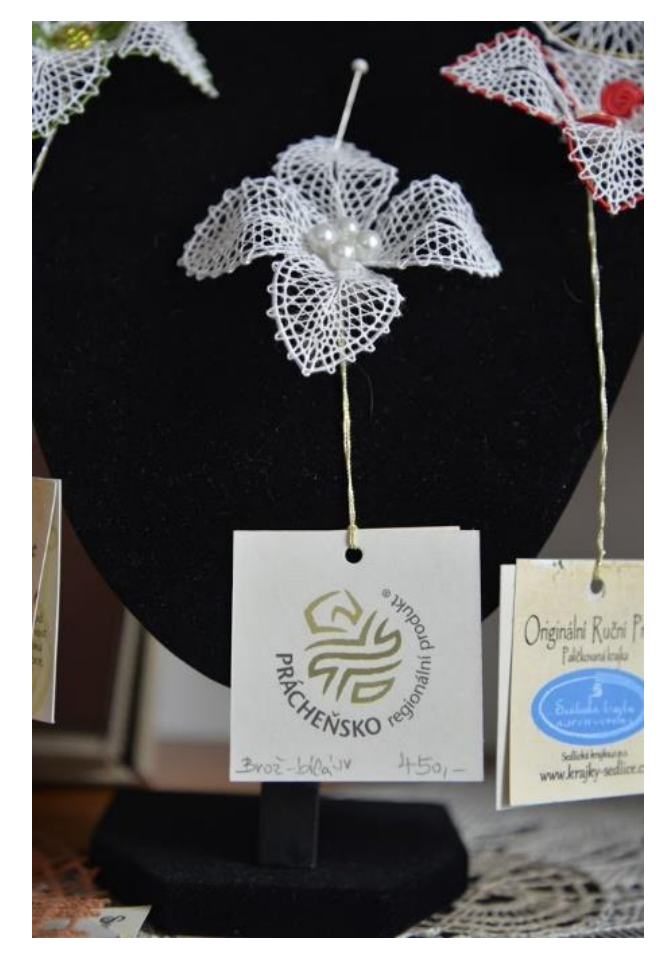

\section{inspirace pro vzdělání}

Jana Dlouhá, Lucie Švecová, Jiř̌i Dlouhý, Rhys Evans
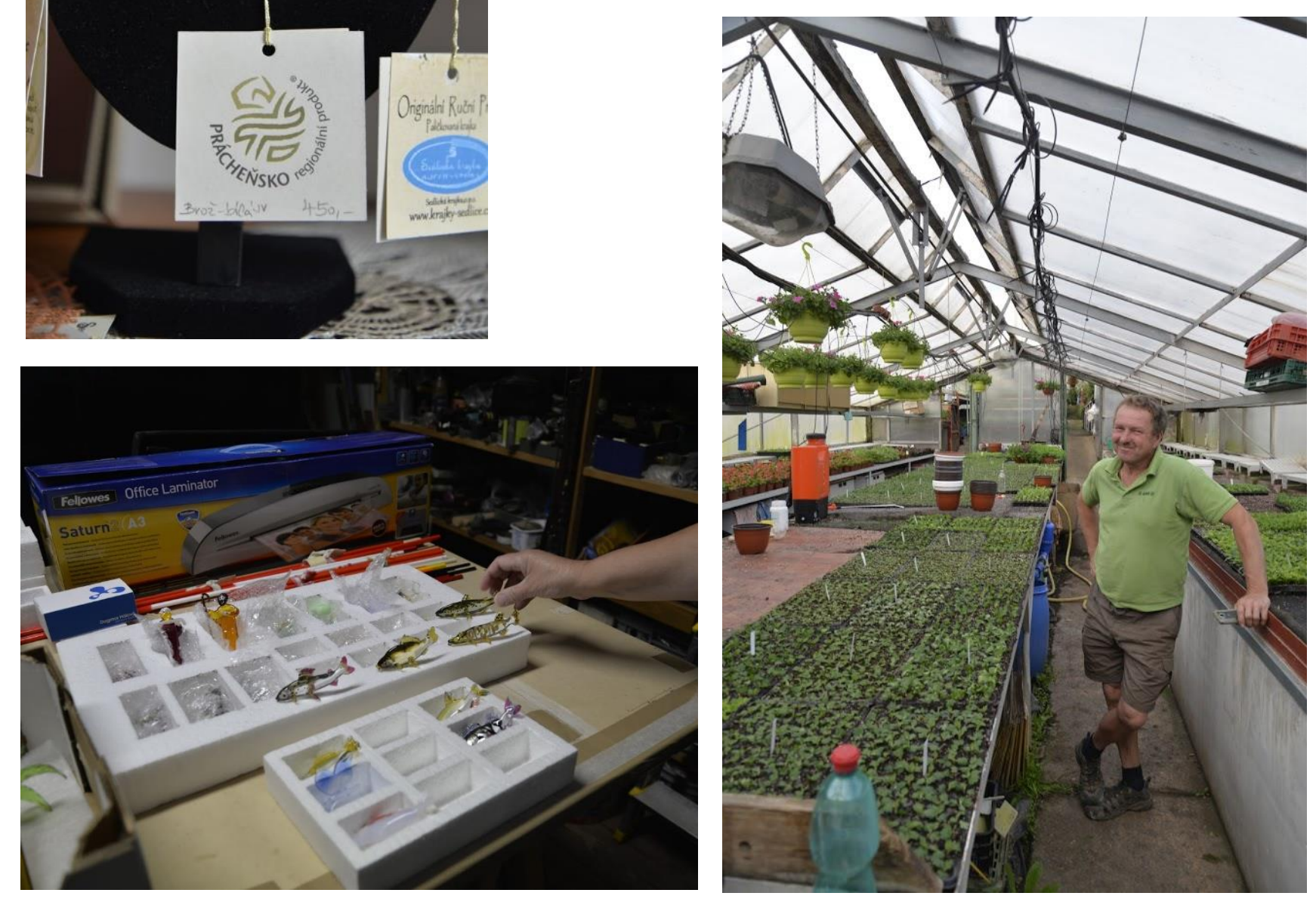
Centrum pro otázky životního prostředí Univerzita Karlova

Regionální centrum expertizy Česko
Environment Center Charles University in Prague
Centrum pro otázky životního prostředí Univerzita Karlova v Praze

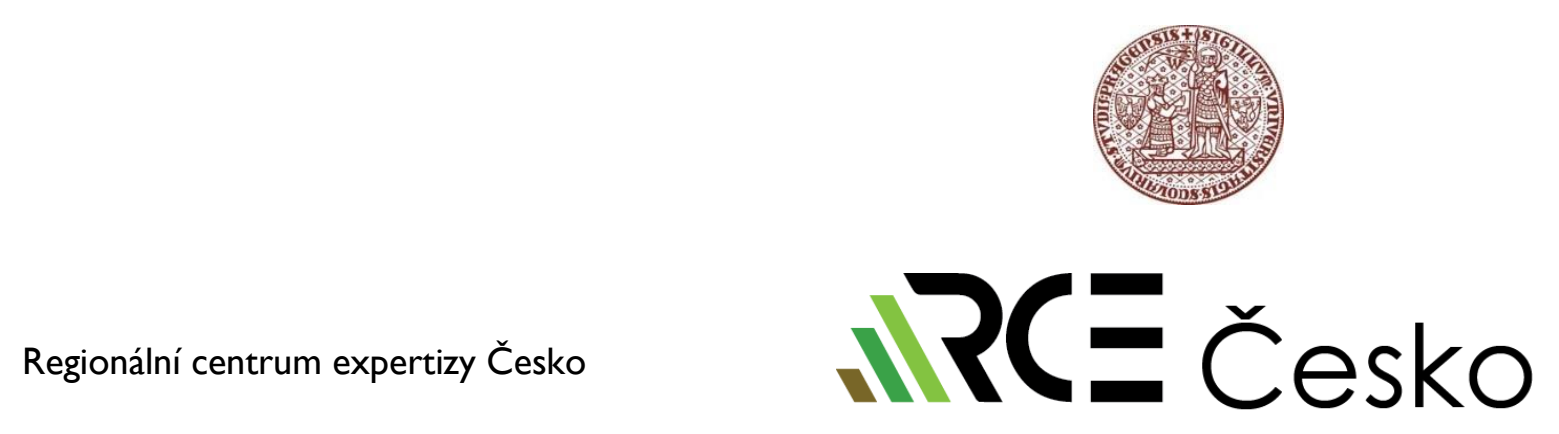

(c)

V Praze dne 3I. 5. 2017

Podpořeno z Česko-norského výzkumného programu CZ09

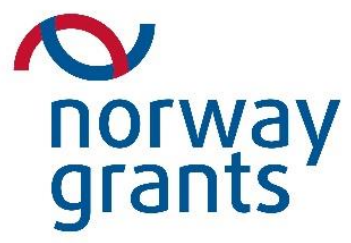




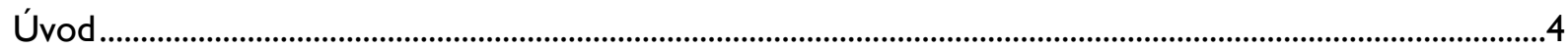

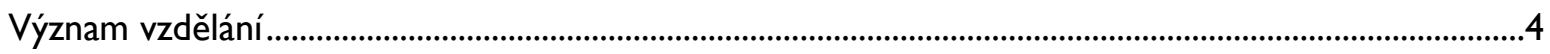

Drobné podniky v místní ekonomice ............................................................................................

Jak jsme se dozvídali o dnešním podnikání na venkově...........................................................................5

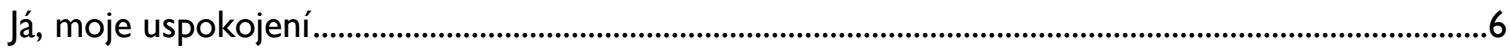

Rodina

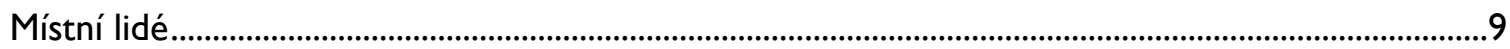

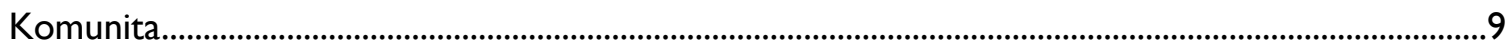

Vztahy s jinými podnikateli a zákazníky.......................................................................................... 10

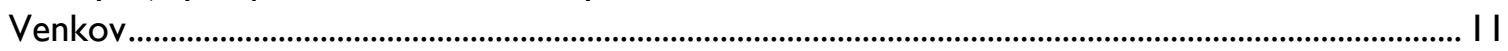

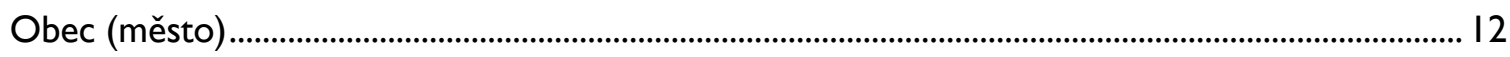

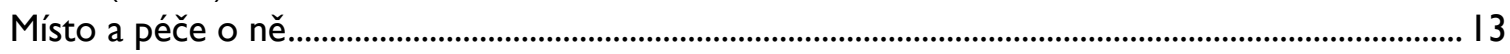

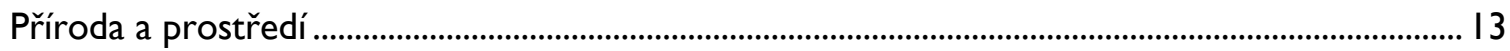

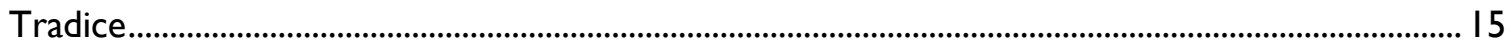

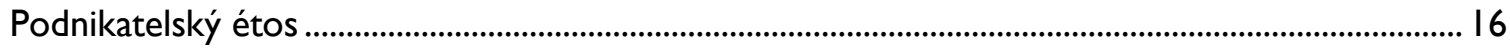

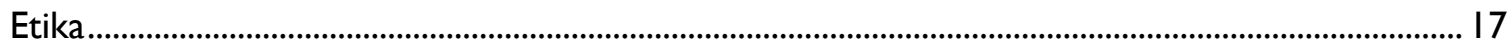

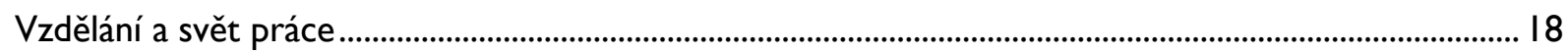

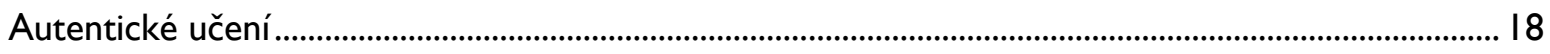

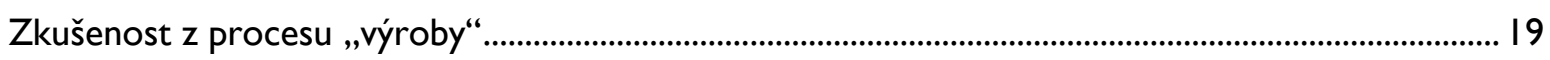

Autenticita $\vee$ místním podnikání................................................................................................................ 20

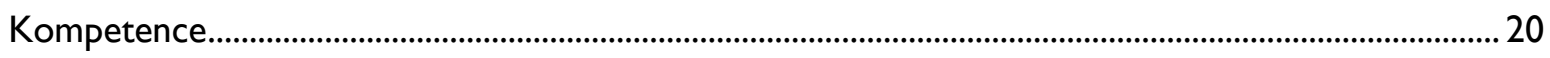

Nadšení pro věc - a vytrvalost ....................................................................................................... 2 I

Návaznost na (rodinnou, místní) tradici ............................................................................................ 2 I

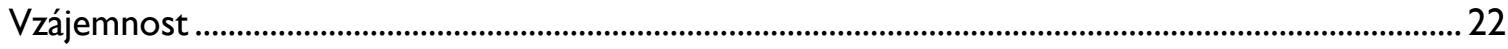

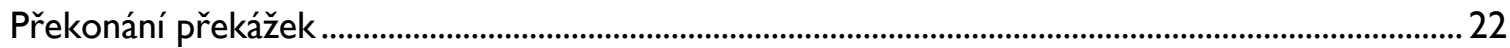

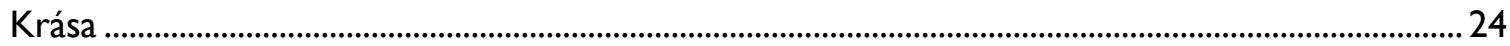

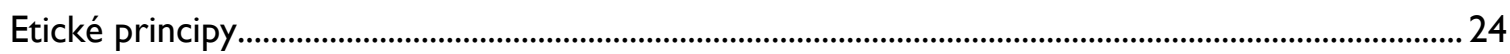

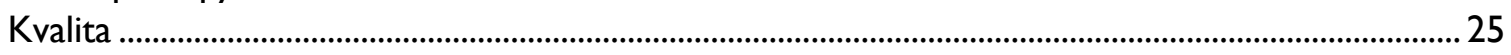

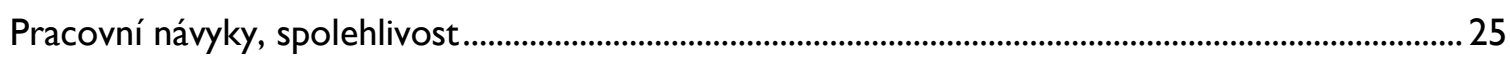

Učit se novému.

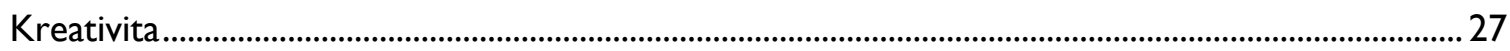

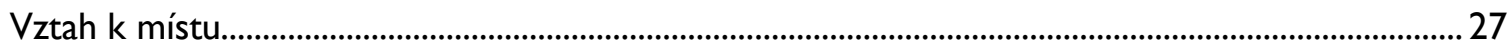

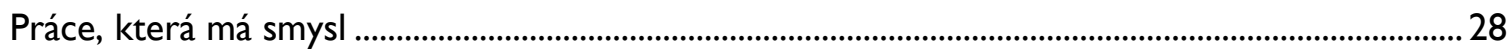

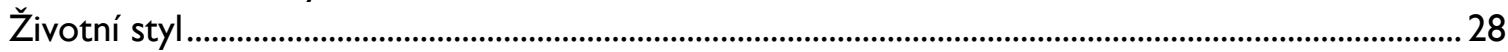

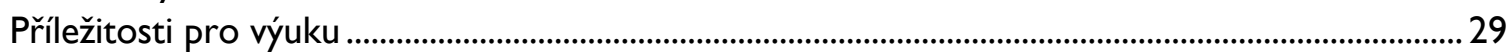

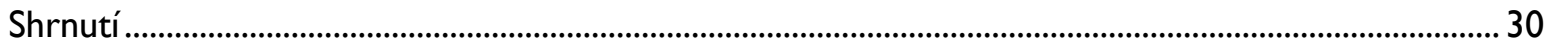

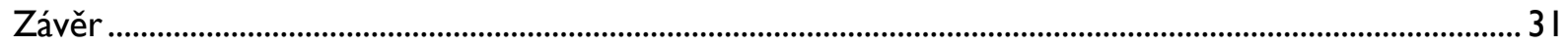

Podnikatelé, kterých jsme se ptali ( $v$ abecedním pořádku) ……….................................................... 3 I

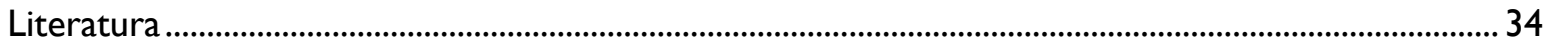


Výrok rodiče: „Dnes už se peníze nevydělávaji praci!““

Žijeme sice $v$,postfaktické“ době, vychovávat své děti pro ni bychom ale neměli

- aby nám príležitostně neoznámily, že do̊ležité věci se už nedozvídají učením.

\section{Úvod}

Současný rozvoj by měl přinášet výhody (nikoli ohroženi) budoucím generacím, a to stejnoměrně v oblasti ekonomiky, životního prostředí, i života společnosti. Na této myšlence je založen pojem mezigenerační rovnost (Padilla, 2002), který tak těsně souvisí s obecně přijatou definicí trvale udržitelného rozvoje. Jedním z důležitých nástrojů, jak takového rozvoje dosáhnout, je vzdělávání - to by mělo nejen učit mladé lidi o současných problémech životního prostředí, ale také je inspirovat k tomu, aby se sami přímo podíleli na udržitelné ekonomice: svou každodenní činností i při volbě budoucího povolání. To je velmi důležité hlavně pro venkovské oblasti v Česku, mj. aby se zabránilo vylidňování venkova $v$ důsledku měnících se podmínek pro zaměstnanost. Počet pracovních míst v zemědělství se neustále zmenšuje, protože roste využivání mechanizace a strojní práce, která v klasické venkovské výrobě (zemědělství, lesnictví, rybolov, těžba atd.) nahrazuje práci lidskou. Vytváření nových příležitostí k zaměstnanosti, většinou na principu samostatného podnikání, tedy umožní obyvatelům venkova se zde uživit, ale nejen to - často se tak mohou zapojit do „zelené ekonomiky“ tím, že vyrábějí a dodávají zboží a služby při využití udržitelných, $k$ prrírodě šetrných postupů.

Naštěstí evropská politika v posledních desetiletích má za cíl ochránit zdroje, které se přirozeně nacházejí ve venkovských oblastech - což je nejen místní kulturní a historické dědictví, příroda samotná, ale také napřiklad krajinné scenérie, tradiční výrobky, postupy jejich výroby i místně jedinečné aktivity. Tyto zdroje mohou být důležitým základem prosperity nových podniků, které chtějí uspokojovat rostoucí požadavky městského obyvatelstva na ,autentickou“ zkušenost anebo zážitek ve venkovském prostředí. Obyvatelstvo na venkově by mělo umět rozpoznat jejich hodnotu, a zúročit ji právě v ekologickém podnikání. Zde hraje důležitou roli vzdělání - zvláště mladí lidé by měli znát místní zdroje, a na jejich základě si hledat stávající, nebo vytvářet nové př́ležitosti k obživě, a to v místě, kde vyrostli. Pokud se určité schopnosti a místní znalosti nebudou rozvijet, bude těžké zabránit vylidňování a demografickému úbytku v rozsáhlých územích. Venkovské komunity se stanou nefunkčními, a celkově bude těžké zajistit obnovu a rozvoj venkova. Takovému nepříznivému vývoji v současnosti čelí venkovské oblasti v českých zemích, a tento trend nelze zvrátit bez odpovídající prrípravy těch, kterým záleží na místě, kde žjí. Vzdělání tedy může pomoci, aby náš venkov byl krásný nejen jako turistická destinace, ale především jako místo k životu, kde bychom se mohli potkávat se zajímavými lidmi a jejich (smysluplnou) prací - což jsou cíle, na kterých máme zájem všichni.

\section{Význam vzdělání}

Vztah vzdělávání k (místni) ekonomice je oboustranný. (Určité) vzdělání je nezbytným předpokladem (ekonomické) úspěšnosti v podnikání; na druhé straně mohou být drobné ekonomické podniky nevyčerpatelným zdrojem příležitostí se naučit něco nového, co je podstatné pro život i vlastní práci. Učení a udržitelný rozvoj totiž spolu př́mo souvisejí. To se zjistilo již v roce 2007 v projektu společnosti Euracademy, která se zaměřila na celoživotní učení a udržitelný rozvoj (Evans, 2007). Zde bylo jasné, že nejen vzdělávání mưže zásadním způsobem pomoci jednotlivcům a komunitám, které se chtějí nebo musí přizpůsobit společenské situaci a změnit vlastní hospodaření, ale že učení přímo přispívá $\mathrm{k}$ růstu těchto odvětví vytvářením přiležitostí pro místní obyvatele. Mladé lidi je totiž třeba učit o výzvách a přiležitostech souvisejících s trvale udržitelným rozvojem a místní správou. Ale nejen to - je také nutné, 
aby dokázali hledat inovativní postupy, jak využít tradiční produkty a služby. Důležitou úlohou vzdělávání tak je nabízet žákům/studentům nástroje $\mathrm{k}$ tomu, aby viděli skutečnou hodnotu ve zdrojích, které mají po ruce, a dokázali také najít konkrétní možnosti, jak reagovat na nové požadavky trhu. Tím by se mohli úspěšně zapojit se do nové, udržitelné ekonomiky.

\section{Drobné podniky v místní ekonomice}

Potřeba udržitelného rozvoje venkovských oblastí má ovšem i svou druhou stranu - osobní. Hospodaření, které se zde má rozvijjet, musí být udržitelné a „ziskové“. Nejde přitom jen o peníze, které zde hrají roli. „Ziskem“ je i kvalita života, spokojenost, možnost seberealizace - to všechno jsou důležité motivační faktory, které stojí za úspěšným podnikáním v tzv. „zelené“ ekonomice. Díky těmto podnětům může být samostatná výdělečná činnost zajímavá pro jednotlivce; v místní komunitě pak může přispět k obnově jejích životně důležitých funkcí. Spokojenost a pevné místo jedince v místním společenství jsou faktory, které pomáhají mladým lidem rozhodnout se pro udržitelné podnikání a setrvat $v$ něm delší dobu.

Tyto závěry jsme si udělali po několika rozhovorech s malými českými podnikateli, kteří využívají místní zdroje, jako jsou tradiční zemědělské a kulturní výrobky, zboží a služby, napríiklad historicky známé, dávno používané potraviny. $\vee$ několika tzv. „hloubkových" rozhovorech, které jsme vedli s 20 podnikateli od poloviny roku 2016 do poloviny roku 2017 ,

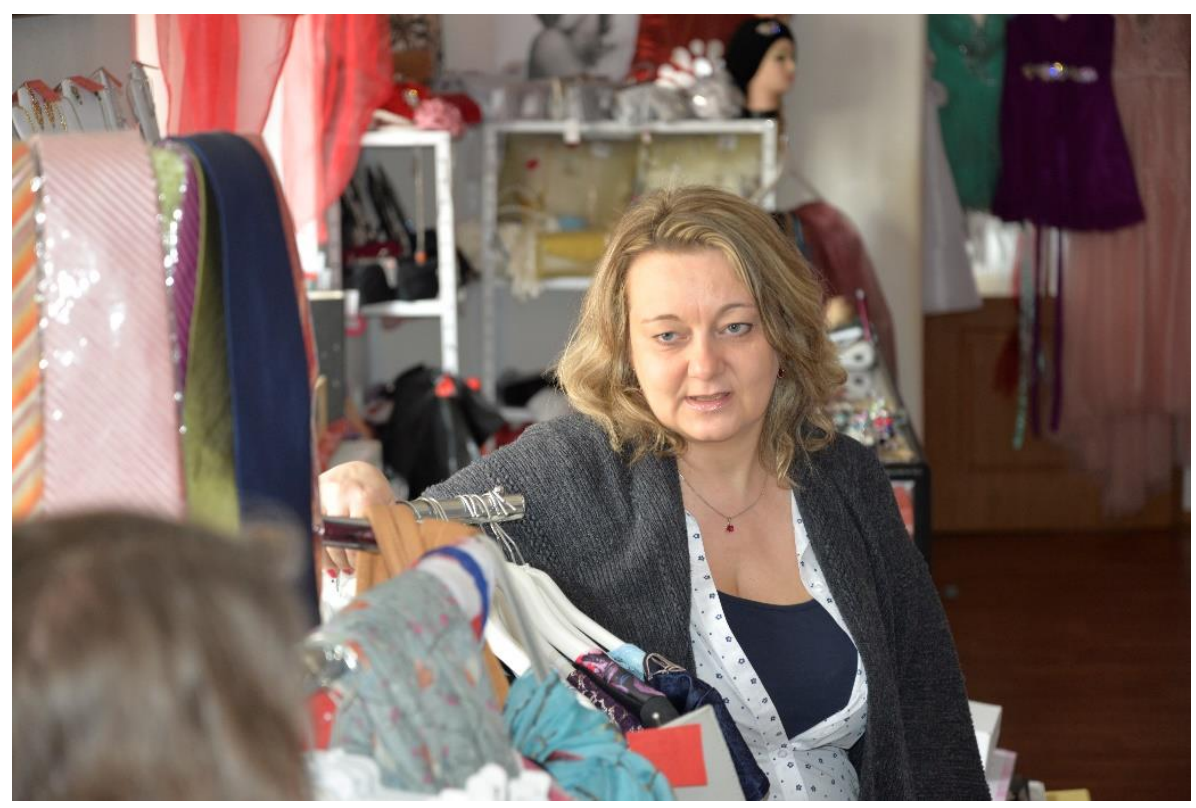
jsme se ptali především na osobní, přímo se jich dotýkající stránky rozvoje podnikání. Naši „,respondenti“ odpovídali na otázky typu: Je výsledkem Vaší činnosti osobní spokojenost? Jaký je Váš vztah se stávající komunitou a jejími podnikateli? Jak Vaše podnikání odráži Vaše vlastní hodnoty, či potřeby a dovednosti? V následující části představíme některé z nejzajímavějších odpovědí. Snad se tak vysvětlí, proč a jak se využití tradičních postupů, které přispívají k tvorbě či zachování kulturního dědictví, může stát povoláním, jež člověka osobně naplňuje.

\section{Jak jsme se dozvídali o dnešním podnikání na venkově}

Abychom zjistili, jak se dnes žije a pracuje na venkově, ptali jsme se drobných podnikatelů - které jsme znali či je náhodou potkali, kteří ale byli něčím výjimeční. Všichni svou práci milovali, věnovali jí veškerý svůj čas, a většinou nečekali, že ze své tvrdé práce zbohatnou. Odměnou jim byla sama skutečnost, že jsou svobodní, rozhodují o svém životě a jeho čase, v němž dělají to, co považují za smysluplné. Podobně, jako jim záleželo na poctivosti vlastního života (vždy toužili, aby jejich práce měla hmatatelný výsledek a byla užitečná pro ostatni), měli také velmi upřímný vztah ke svému prostředí a lidem, kteř́ je obklopovali. Musíme tedy jen doufat, že tento „,vzorek“ 'lidí trochu odpovídá celkové skladbě obyvatel 
- že takových, jako oni, je v naší zemi více. A to přesto, že současné „podnikatelské prostředi“ jim jejich snažení rozhodně neusnadňuje.

$\checkmark$ následujících kapitolách budeme sledovat, jaký význam má drobné podnikání pro samotného člověka, který se jím zabývá, pro jeho blízké i ve vztahu $k$ širšímu společenství obce nebo městečka; jaký má vliv (dle výroků dotázaných) na prírodní i společenské prostředí. Dozvíme se, jak se $v$ jeho rámci upevňují vztahy s dalšími lidmi dnes, $i$ proč je třeba navazovat na kulturní tradice minulosti. Druhá část této publikace je pak věnována dovednostem, které se při (tradiční, často řemesIné, manuálni) práci pěstují, a jak by je mohl uchopit vzdělávací systém, aby se tyto často jedinečné schopnosti postupně nezapomněly. Domníváme se totiž, že přes svou výjimečnost ( $v$ současné době) patří mezi definiční znaky člověka. Bez nichž by lidé nebyli tím, za co je stále ještě pokládáme.

Seznam podnikatelů, s nimiž jsme byli $\checkmark$ kontaktu, a stručný popis jejich podnikání, najdete na konci tohoto textu a také $v$ našem otevřeném elektronickém zdroji, který má složit podnikatelům, viz www.enviwiki.cz (portál Podnikání, kapitola Příklady drobných udržitelných podniků na venkově). Text, který zde předkládáme, je za-

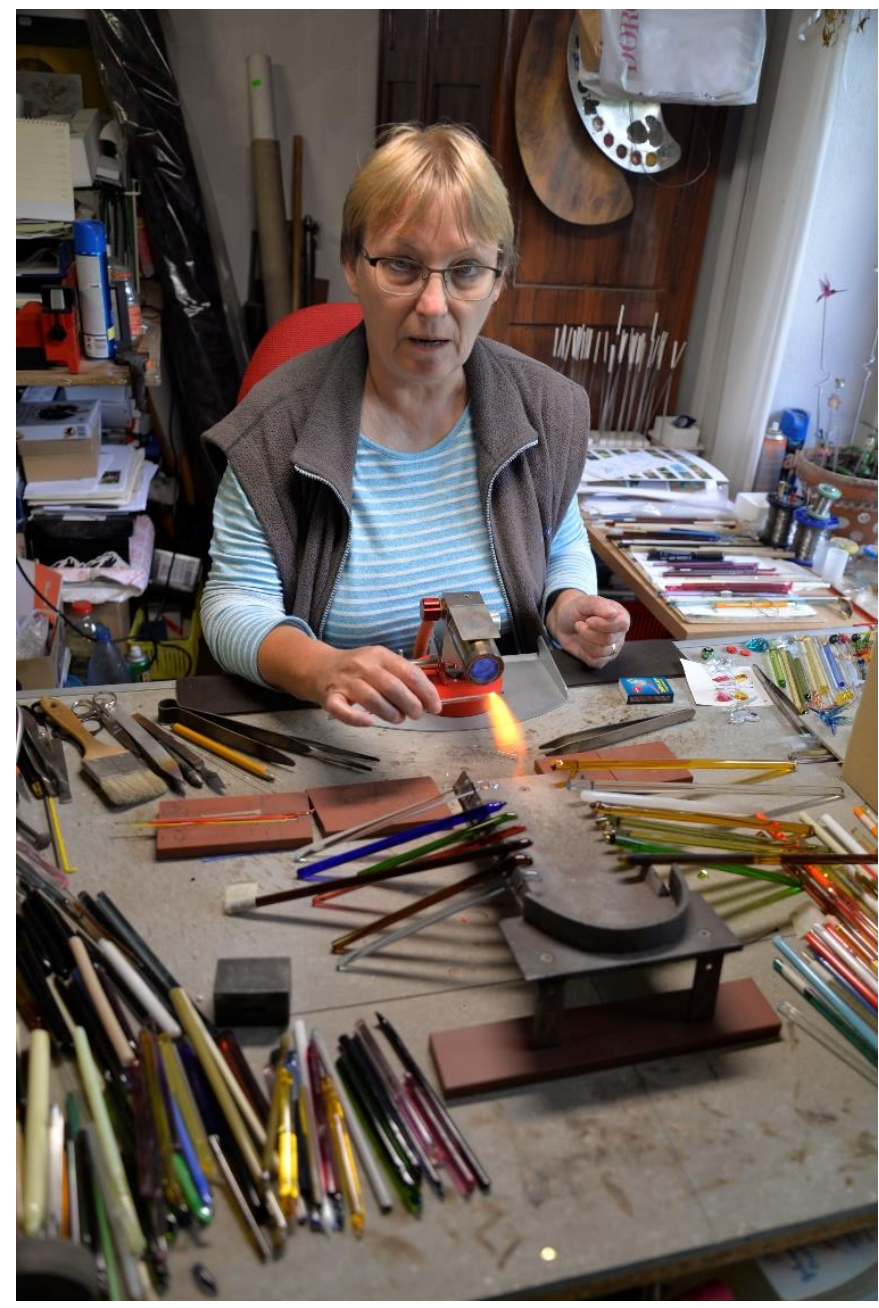
ložen na jejích výpovědích. Naší zásluhou je pouze jejich uspořádání doplněné vysvětlujícími komentáři. Přejeme př́jemné čtení!

\section{Já, moje uspokojení}

Cíle podnikání jsou samozřejmě ekonomické, a úspěch v této oblasti je hlavním důvodem spokojenosti. Nicméně když jsme se na spokojenost zeptali, zjistili jsme, že často ne nejdůležitějším. Podle množství stejných odpovědí to vypadá, že největším štěstím při této práci je pocit svobody. I když je namáhavá a někdy se člověku nedaří, je to pořád na něm samotném, aby svou situaci zlepšil: „Chtěl jsem být vždy sám sobě vlastním pánem, to mi podnikání umožňuje a to mě motivuje $k$ podnikání. Mít kontrolu nad tím, co dělám, nenechat si od nikoho poroučet." (R20). Aby se člověk dokázal těšit z přítomného okamžiku, je ovšem nutné se osvobodit také z přehnaných materiálních nároků... „Takto mi to vyhovuje, nemám skoro žádný stres. Jsem pánem svého času a to mi stači. Jsem spokojený, co si udělám, to mám.“ (R/3) .... spokojenost hledat $v$ každodenních radostech: „Každé ráno vyjdu a jsem $v$ práci, to je tisíckrát lepší než někde osm hodit denně sedět za počitačem a nechat na sebe křičet. Každodenní kontakt s prírodou je pro mě nejcennějši faktor mé práce.“ (R/5). Samostatné podnikání je i způsobem, jak se nejen osvobodit, ale také emancipovat: „Osobní svoboda je pro mě pozitivním aspektem podnikání. Jsem zodpovědná za své činy.“ (R/8). Motivy osvobození od společenských stereotypů, a prijijetí odpovědnosti za vlastní život zazněly často, $v$ dalších př́ípadech, které zde už neuvádíme. 
Kromě potřeby osobní svobody pocit'uji lidé také nutnost o své práci přemýšlet, zkoušet a hledat nové možnosti a postupy. Říká se tomu kreativita, jde ale o normální postup práce - od myšlenky k jejímu uskutečnění - který plně závisí na naší fantazii i odpovědnosti: „,Ty šperky vlastně začaly proto, že jsem se potřebovala opravdu silně kreativně vyjádřit. Výroba ze skla mi byla od začátku blízká. Jenže pak jsem zjistila, že šperků mám doma opravdu moc a tudiž jsem si nechala zaregistrovat regionální značku a začala jsem je prodávat. ... No ale jinak žádná úskalí nebyla, ale to je asi díky tomu, jak k těmto věcem přistupuji - tedy jako ke svému koníčku, který mi obohacuje život“ (R7) Taková práce člověka uspokojuje - smysl je v ní samotné; nebývá ale dostatečně hodnocena finančně: ,Jsou to ale hlavně krajkářky, které do mistního obchodu přispivaji svými výrobky. Jejich motivace nemá finanční charakter. Tato práce je opravdu náročná a finančně nemůže být oceněna, tak jak by zasluhovala. Prostě je to baví a naplňuje je to, že dělají rukama, něco kreativního.“ (R/4). Svou roli hraje i touha sdílet nové objevy, které se při vymýšlení jedinečných postupů někdy samy urodí: „Ano chtěla jsem kuchařkou pomoci lidem se stejným problémem. Neumíte si představit, jak je složité tuto dietu dodržovat a pritom si zachovat rozmanitý a vyvážený jídelniček. Já sama jsem kolikrát byla hlady a prišlo mi líto se pak o své nápady a znalosti nepodělit s ostatními.“ (R7). Přání podělit se o zkušenosti, kromě předávání konečného výrobku, je samostatným tématem, o kterém se naši podnikatelé často zmiňovali. Sdílená radost se ukazuje být „hybnou silou“ podnikání v dobách dobrých i zlých: „Každá nová prodaná věc mě motivovala se tomu věnovat dál, vymýšlet nové věci, nové vzory. Pro mě osobně to bylo velmi obohacujicí a jsem za to št’astná, i když vím, že podnikání v pravém slova smyslu to nebylo.“ (R7).

Prací je možno plnit si své dlouholeté sny - v tom, co lidé chtějí dělat (a dělaji), nalézají smysl života: „Počátkem byla moje vášeň pro koně, které jsem si od malička prála chovat. ... To byl pro mě do té doby sen, který jsem si myslela, že je nevyplnitelný. Nicméně v roce 1984 jsem si pořidila svého prvního koně a tím to vše začalo. ... Pokud se půjdu podivat na pastvu a uvidím tu čtyřnohou nádheru, pak vím, že to dělám správně. Nezáleží mi na tom, co řikají moji odpưrci, záleží mi na tom, co cítím já." (RI2). Aby však byl uskutečnitelný, a dlouhodobě udržitelný, je nezbytné systematické budování podniku: ,Je to moje historie. Než jsem prevzal tuto společnost, tak jsem pro ni sám pracoval pres dvacet let, nechal jsem tam kus života, pomohl jsem zlepšit produkci, dotáhl jsem to $k$ tomu, že se dnes jedná o slušně fungující firmu se slušnými zviŕaty. ... To mě opravdu těši.“ (R9). Úsilí vložené do podniku přináší (tvrdě zasloužené) výsledky... „Vidím že se nám daři, vidím kolik toho už za námi stojí, kolik jsme toho vybudovali. Je jasné, že je to vždy spojené s tou dřinou, nejezdíme na dovolené, jsme porád tady, ale neměnila bych. Nedovedla bych si prèdstavit dělat pro někoho cizího, někoho poslouchat, jsem svým pánem a jsem svobodná." (R/8) ... a tyto

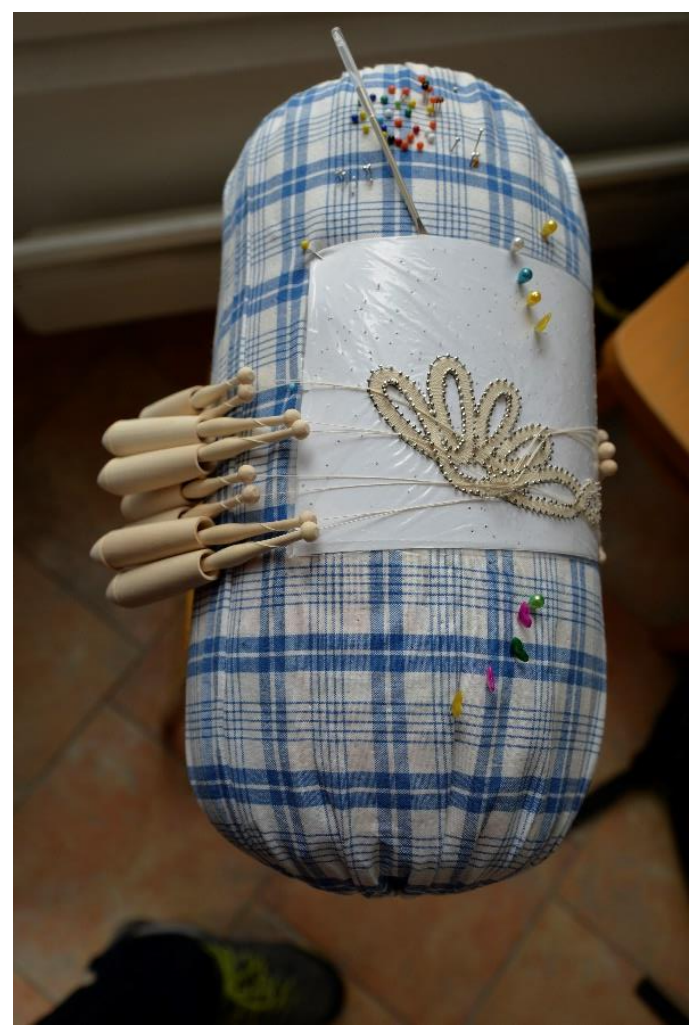
výsledky se postupně sčítají: „Na něco jsme byli připravení, ale na něco ne. Mnoho přiležitostí jsme jistě prošvihli. Ale tou dřinou od rána do večera jsme se nakonec někam dostali, dostali jsme se $k$ lidem, $k$ zákazníkům. Pro mě je podstatné, že si zákazníci pro zboží přijedou, že vědí kde nás najít a že my nemusíme jezdit za nimi.“ (R2).

Práce, kterou člověk miluje, sám si ji plánuje a řídí, a současně pokládá za službu druhým lidem a prostředí, dává možnost naplno si prožít vlastní úspěch: „Láska ke koním a k prírodě, podpora komunity, a asi $i$ historie - dělám chov pres třicet let $a \mathrm{z}$ mého pohledu by byla škoda toto zahodit. Chov $a$ úspěchy $v$ něm - např. na přehlídkách, nebo na vytrvalostních závodech - mi přináší největší radost a motivaci pokračovat.“ 
$(R / 2)$. Někdy jsou ale prríčiny úspěchu jednoduché, přímočaré: „No jsem to určitě já, z čeho pramení moje energie? To nevím, prostě mě to baví. (R9)

\section{Rodina}

$\checkmark$ rodinném podniku pořád ještě funguje tradiční model generačního předávání/učení, kdy řemeslo přechází z otce na syna (nebo z matky na dceru). Láska mezi členy rodiny se stejnou měrou týká $\mathrm{i}$ společné práce: „Ano - otec byl kovár. Nejen otec byl motivací. Odjakživa jsem chtěl podnikat, a protože jsem se $v$ kovářstvilpodkovářství vyučil, tak jsem začal podnikat v tomto oboru. Chtěl jsem dělat práci, ve které jsem vyrůstal a ve které se vyučil. Na venkově jsem vyrůstal a je to můj domov.“ (R/6)

Vztah mezi generacemi je často ukotven $v$ majetku, který se $v$ průběhu let $v$ rodině dědí - a je potřeba se o něj starat, dále rozvíjet jednou založené bohatství. $O$ tom hovořili mnozí $z$ těch, jejichž rodiny pečují o rodinné dědictví: „Celé podnikání jsme začali v roce 1990 těsně po revoluci. Nechali jsme si vrátit pozemky, které patřily mým prarodičům. $V$ roce 1995 jsme celou zemědělskou činnost s mužem kompletně přvzali. Na pozemkách a $v$ usedlosti mé babičky jsme začali hospodarit a tím to všechno začalo. Nemám zaměstnance. Jenom rodina.“ (R/8) Nebo: „Ano, naši v zemědělství podnikali a já jsem to po nich jednoduše převzal. Psal se rok 2004, bylo mi 22 let. Bylo přirozené podnikání převzít.“ (RI9).

Pěstuje se tak mezigenerační odpovědnost. Na otázku: Mohl/a byste charakterizovat svůj úspěch? jeden z dotázaných odpověděl: „Ano, žijeme, jsme tu, mám tady maminku a tatínka.“ (R4) Práce představuje pro členy rodiny i sdílený zážitek - tak se společně piše historie rodiny: „Kdyby člověk neměl radost $z$ práce, tak to nedělá. Výhoda je, že to děláme $v$ rodině. Když se mě na tohle někdo ptá, tak odpovídám, že chci a pak už musím. Samozřejmě, že práce v rodině přináší jak pozitivní, tak i negativní okamžiky.“ (R5). Členové rodiny si prostřednictvím společné práce vzájemně pomáhají: „,K rozhodnutí ... provozovat vesnickou hospodu přispělo hned několik důležitých faktorů. Prvním byla touha změnit styl života a najít si koníčka. Druhým bylo studijni zaměření dětí. Syn i dcera se rozhodli pro pohostinskou činnost, a jelikož sháněli sezónní zaměstnáni $v$ oboru, rozhodli jsme se umožnit jim práci ve svém." (R6). Zaměstnávat rodinné př́slušníky je však i výhodné pro podnikání: „...podnikáme $v$ rámci rodiny. Konkurenci to stoji penize, aby měli prodavačku $v$ prodejně mimo sezónu. No a my bychom

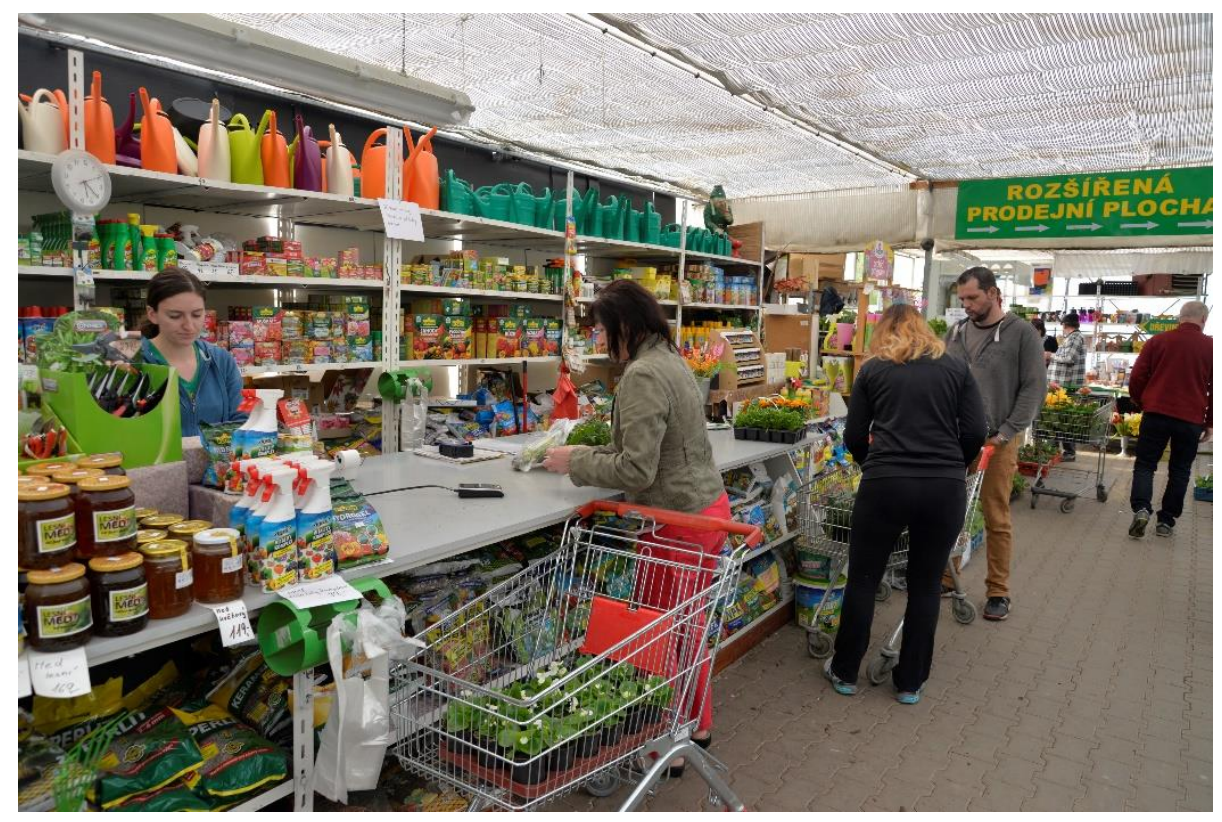
tam stejně museli být“". (R2).

Ale hlavně - rodinná práce je výborným výchovným prostředkem. Jak jinak by se děti naučily odpovědnosti, nebo dokonce obětavosti pro ostatní členy rodiny? „No ze začátku to bylo těžké, nespali jsme, doma dělali prakticky všichni. Děti jsme měli malé, ale museli jsme zkombinovat je i práci po večerech. Děti se učily rychle, pracovali s námi, dokonce se o nás starali - dělali nám večeři..." (R2). Společná práce tak často představuje dokonce ideál rodinného života, kdy se přirozeně utváří zdravé psychosociální 
prostředí pro všechny členy rodiny (a vztahy mezi nimi), nezávisle na věku: „Celá rodina máme pocit naprosté smysluplnosti, děti nám vyrostly v tomto zdravém prostředí, jíme to, co si sami vypěstujeme, $a$ vždy prijide někdo, kdo vyvalí očička, kdo řekne, že jsme úžasni a že nás obdivuje ..." (R4).

\section{Místní lidé}

Podnikání, o které nám jde, se nedělá pro zisk a osobní prospěch. Je to práce, která dodává životu celkový smysl. K tomu patří vztah $\mathrm{k}$ lidem, pro které je práce nějak užitečná. Sdílení radosti z pracovního procesu i jeho výsledků je důležitým motivem - a to nejen pro práci samotnou: „Na podnikání mě těši, že ti druzí z toho maji radost. I když je Drachkov malá vesnice, tak vím, že lidi těší, že tady ta hospoda je a já mám tak stále zákazníky. To že jsou lidé takoví, jací jsou, mi dokonce pomohlo překonat i těžké životní období. ... ta vazba na lidi je v hospodě to nejpodstatnější - pokud totiž nepríijdou, tak múžete rovnou zavřit.“ (R6).

Dobrý vztah k lidem není ale prostým důsledkem práce pro ně - na vztazích je třeba pracovat, investovat hodně empatie a postupně budovat vzájemnou důvěru, aby dlouhodobě přinášely radost a užitek oběma stranám: ,Jsem trochu jako psycholog, hodně lidí mi věři a během príprav svatby mi svěruji i své priběhy - jak pozitivní, tak i negativní. Myslím, že to, že mi mohou věřit je jeden z aspektů, proč se ke mně vraceji.“ (R3). Jako tmel těchto vztahů působí důvěra - je potřeba ji oplácet... „V tomto podniku jsem se těšil důvěře lidí, to mě asi motivovalo nejvíce.“ (RIO) ... anebo prostě poskytovat potřebným ... „V podnikání mám lidský přistup, snažím se lidem vyhovět. Dávám lidem druhou šanci.“ (RIO).

\section{Protože dobré vztahy stmelují ko-} munitu, utvářejí širší společenství, rozvijejí se lépe $v$ menších městech či na vesnicích: „Dobré je to $v$ tom, že získávám mnoho nových přátel. Lidé mě berou skoro až jako rodinu. Já si dokonce myslím, že pro mé podnikání je lepši menši město, než větší. Známé mám ted' všude, ale pak je dobré, že máte podporu, hodně lidí vám pak rádo pomůže." (R3). Někdy ovšem - z hlediska síly vztahů - nehraje roli ani velikost tohoto společenství: „Moji zákazníci již jsou z velké části i práa-

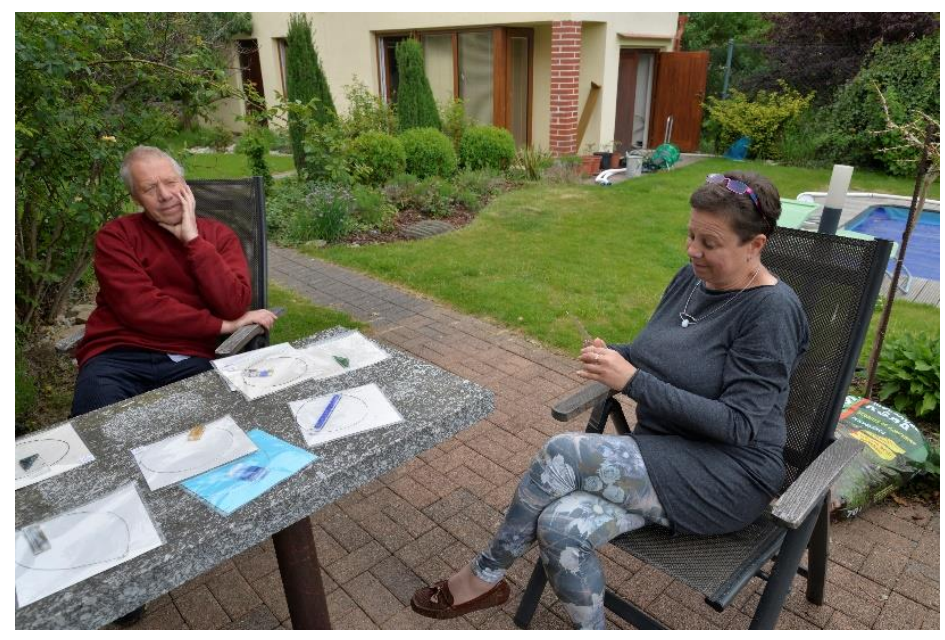
teli. Jak $\mathrm{z}$ vesnice, tak z města téměř ve stejném poměru.“ (RII). Záleží nejspiš i na vnitřní, citové investici. Ke vztahům, které jsou důležité v místě, je totiž nutno připočítat i vztahy mezigenerační - které se rozvijejí v čase, udržuji tradice a vytvářejí určitou kulturní identitu: „Podnikání nedržím kvůli rodině, vím, že děti moji práci dělat nebudou. Myslím, že mě tedy nejvíc motivuje ta tradice pekařství ve Vodňanech a lidé, kteři pro mě pracuji." (RIO).

Někdy ale není vše tak idylické, protože my Češi si přece jen s sebou neseme jisté dědictví minulosti „...jako negativní vidím ztrátu soukromí ... další negativum, které si uvědomuji, je ta naše česká povaha prostě závist..."(R3).

\section{Komunita}

Práce pro lidi a pěstování vztahů v rámci místního společenství jsou vzájemně výhodné: „Podpora komunity u mne hrála vždy velkou roli. Narodila jsem se zde, a od začátku cítím sounáležitost a hrdost. Navíc mi opravdu jde o budování a zkrášlování prostředí, ve kterém žiji. Proto je práce pro komunitu pro mne důležitou součástí života. Má činnost je navíc komunitou podporována, navzájem si vycházíme vstřic. Já se se svými koňmi účastním komunitních aktivit a prrispívám, oni mi naopak pomáhají s organizací našich aktivit, či mi 
poskytují pozemky na pasení. Vše zde funguje jak má." (R/2). Podnikání tak může příznivě působit na rozvoj komunitních aktivit...: „Vztah k okolí mám velice kladný, obyvatelé mě príijali skvěle a já se jim na oplátku snažím se vším vyjít vstříc. Podilim se na mnoha společenských akcích, snažím se napřiklad mistním spolkům pomoci s organizací a prípravou jejich vlastnich akcí či se dobrovolně sama zapojuji." (R6) ....a naopak dobré vztahy ovlivňují podnikatelský úspěch: „Největší prodejní úspěch jsem měla tady v Čižové. Lidé měli pocit sounáležitosti s komunitou. Kupovali si výrobky od domácího, od někoho koho znají, a to pro ně bylo důležité.“ (R7)

Problém je, že lidé stále více utíkají do svého soukromí a veřejný život by potřeboval podpořit: „Pomalu odpadá ta tradice, $k d y$ lidé chodili do hospody scházet a povídat a řešit komunitní záležitosti. To je $v$ útlumu. Díky tomu se spoustu hospod zavírá ... Můžeme říci, že klasický model, kdy vesnická hospoda sloužila jako místo, kde se lidé scházejí a řeší problémy, ztrácí význam. Lidé tolik nekomunikují, raději jsou doma.“ (R6). Což se stává jevem obecným, jak potvrzuje i další podnikatel: „Za socialismu měla skoro každá vesnička někde budovu, která byla rozdělená na dvě pưlky, $v$ jedné půlce byl místní obchod a $v$ druhé byla pivnice. Lidé se $v$ obou zařizeních potkávali, socializovali se a řešili problémy. Ne nadarmo se říká, že chceš-li něco vyřešit, jdi do hospody. V současnosti jsou tyto podniky z větši části zavřené.“ (RIO).

\section{Vztahy s jinými podnikateli a zákazníky}

Dobrý vztah se zákazníky ovšem celkové sociální prostředí zlepšuje - jeho nejdůležitějším důsledkem není pouze vzájemně výhodná jednorázová akce (prodej a koupě výrobku), často se energie vložená do vztahu vrací dlouhodobě, a to nejen pracovně: „Vemte si, že některé zákaznice jsou tak št’astné, že se jim svatba plní podle představ, že se jim někdo věnuje, že se mi tady dokonce rozbrečí štěstím. To je pro mě tím nejhezčim oceněním, tím co mi dává energii. Se zákazníkama mám opravdu prátelský vztah. Po svatbě nám chodí ukazovat děti, pišou nám zprávy, gratulace. To je to pozitivní na podnikání, to mě nabijí dál.“ (R3). Osobní zisk je v takových př́padech na obou stranách: „Podnikání je dle mého boj, který nikdy nekonči. Nicméně pokud je dobrý vztah se zákazniky, tak ti vám to pak v tom pozitivním směru vrátí. Lidé mě zatím vytáhli ze všeho." (R3). Rozvíjení vztahů je osobním ziskem, pomáhá ale i pracovně: zákazníci nutí podnikatele ke kritickému zamyšlení - zhodnocení, co bylo dobré a kde je potřeba se zlepšovat: „...zpětnou vazbu mám, diky lidem, kteři se mnou následně mluví. Sama si vyhodnocuji, která mi něco přinesla a která ne.“(R4).

Poctiví, své práci oddaní podnikatelé pak tvoří sítě spolupráce založené na podobných zájmech a smýšlení... „...spolupracujeme s místníma živnostníky a podnikateli ... Bud' jsou to kamarádi, nebo jsme na sebe př̌šli $v$ průběhu podnikání a ten vztah se nám vytřibí. Mnohým z nich můžu věrit a mám pocit, že podobné vztahy mezi podnikateli nejsou možné ve městě." (RI) ... $v$ rámci kterých si vzájemně pomáhají:

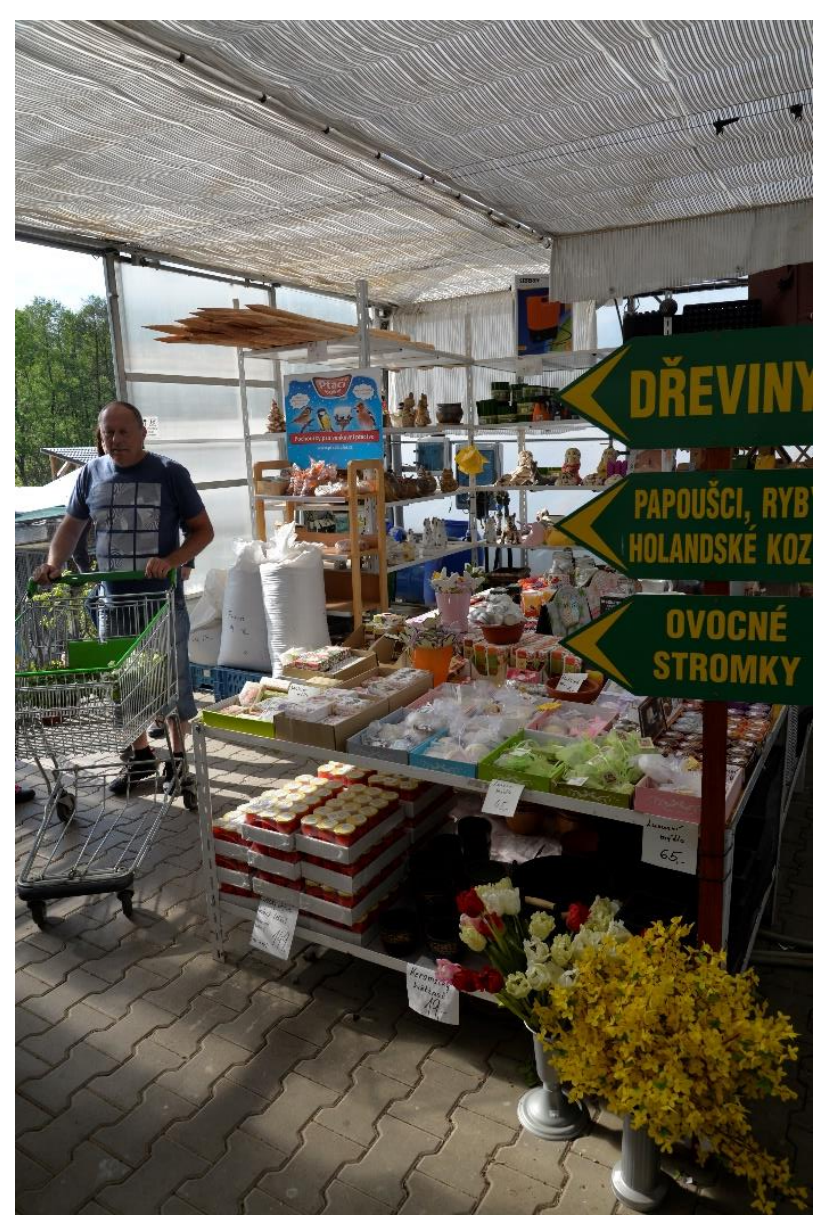
„....máme s ostatními místními prodejci - s cukrářkou, s kadeřnicí, s květinářkou - zavedený systém, kdy na svatbách spolupracujeme dohromady a prihazujeme si zakázky. Toto funguje už od začátku a funguje to skvěle. 
Mám ráda spolupráci s lidmi, kteři jsou na stejné notě, kteři dělají jednodušši věci, které si já pak mohu sama dozdobit, podle stylu svatby kterou pripravuji. Vše jsem se to doučila a můžu říct, že mě to opravdu baví." (R3).

\section{Venkov}

Život na venkově má svou zvláštní hodnotu, jak zdůrazňovala většina námi oslovených: „Podnikání bych nepřemistil do města. Je to stylem života. Ve městě žít nechceme. Pro nás je to skoro za trest, když musíme jet např. do Prahy. Takže chceme žít tady, chceme podnikat tady. A i když by kolikrát príležitosti byly zajímavé, já to nemám zapotřebí.“ (RI). Nejde totiž jen o pracovní, ale opravdu životní prostředí: „Jinak venkov je pro mě životním stylem. Do města a to ani do Prachatic bych nikdy nešel. Po celodenním shonu mě venkov uklidňuje. Jsem myslivec a kolikrát mě uklidní jen ta možnost zajít si posedět na posed." (R9). Venkov poskytuje svobodu, o kterou v samostatném podnikání jde: „Kdybych se měla vrátit třicet let nazpět, i tak bych se nikdy nevrátila, nebo nezačala podnikat ve městě. Na venkově jsem svým pánem, pánem svého prostoru. “ $(R / 2)$ ... a kdo ji okusil, již venkov neopouští: „...popravdě, asi bych se $z$ venkova nehla..." (R8) - důvodů zde zůstávat je totiž mnoho. Většinou se ale musí aktivně vytvářet abychom zakořenili, a potvrdili si tak dlouhodobý smysl svého konání, musíme se hodně snažit.

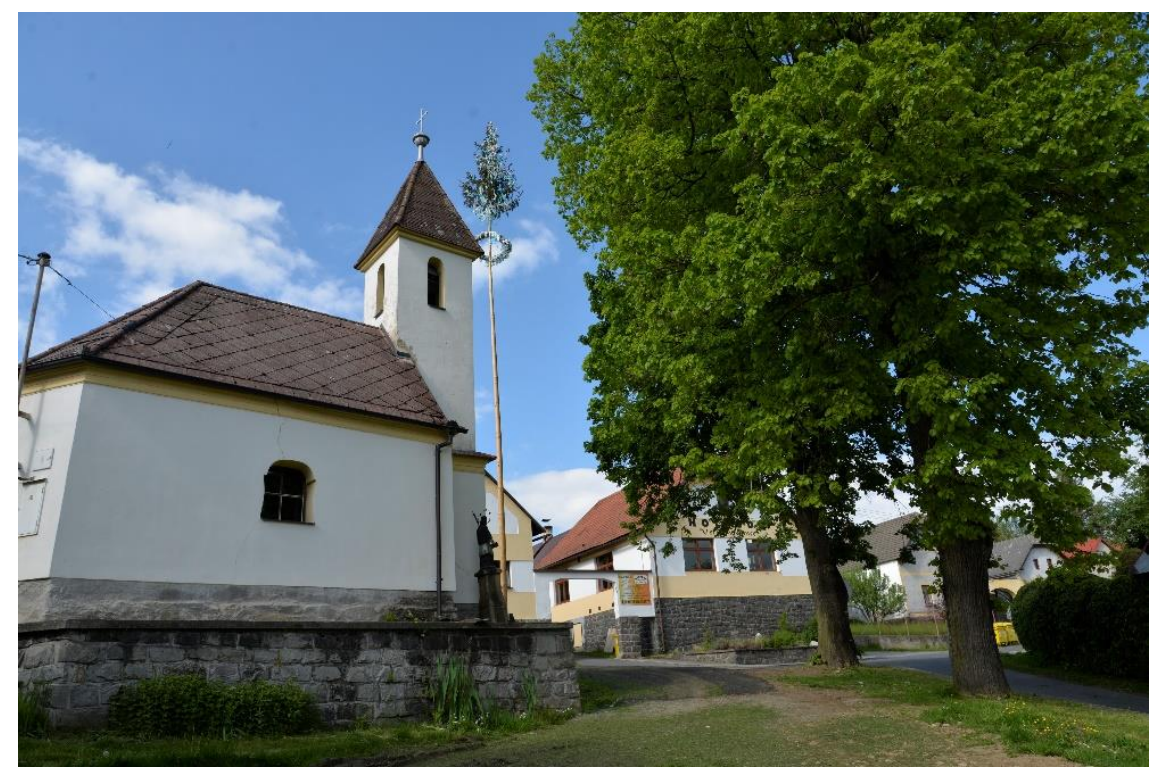

Všechny výhody jsou totiž vykoupeny značnými těžkostmi venkovského života. „Venkov je ztracená varta. Venkov je izolovaný, žádná infrastruktura, pracovní přiležitosti žádné, školy se zavírají, je to konec, naprosto odřiznutý.“ (R5). Kdo chce na venkově být, musí počítat s nepohodlím v mnoha oblastech: „Na vesnici chybí infrastruktura, takže ten kdo jde podnikat na venkov si toto musí uvědomit a musí se podle toho zajistit. Nejde to bez podpory rodiny, nejde to bez úzké spolupráce toho společenství. Musí si uvědomit, že dojet s dítětem $k$ zubaři je problém, že mít čerstvý rohlík na stole každé ráno bude problém ... “(R4). Zvláště podnikání je zde rizikové: „I když prìjde někdo s inovací, nebo něčím v podobě domácích výrobků, tak se na tom venkově neudrží. $A$ to i přesto, že většina z nich má nájem od obce skoro zadarmo a musí si vlastně platit jen elektriku a topeni.“" (RIO).

Těžkosti, které je třeba překonat, ale vedou k odolnosti při prosazování svých cílů - a těmi jsou často „nesystémová“ nebo dokonce ekologická opatření: „Malí farmáři se naproti tomu snaží hospodařit $v$ souladu s prírodou, prodávají produkty ze dvora a to vše bez valné podpory státu. $Z$ mého pohledu je ovšem vesnický člověk tak tvrdý, že vydrži a najde si cestičku sám i bez té jejich podpory. Mám pocit, že nemůžeme čekat na pomoc, ale že si tedy musíme tlačit ten svůj osud prèed sebou a snažit se sami.“ (RI2)

Venkov taky představuje jistotu obživy za všech okolností a v každém režimu: „Mně prijje, že podnikání na venkově je ve své podstatě stabilnějši než podnikání ve městě. Vše na venkově tíhne $k$ zemědělství, které samo o sobě existovalo a existovat bude. Je to mnohem jistější, než rozjiždět nové start-up. Podnikání na venkově je navíc tradičnější. Dělají se zde již zajeté věci. I když možná ty tradice jsou občas překážkou, že se lidi bojí něco inovativního na venkově rozjet, protože to nikdy předtím nebylo." (R2I). Jde tak o přirozenou dělbu práce mezi městem a venkovem: „Na venkově je to uvolněné. Na venkov patř́ zemědělství. Lidé 
jsou zvyklí na techniku i na zemědělskou práci. Vidím smysl $v$ tom jak je to $v$ dnešní době rozdělené - tradiční výroba na venkov a tě̌̌ká produkce do měst.“ (RI9). Jak ovšem dále uvidíme, podmínky pro tradiční výrobu, včetně předpokladů ve vzdělávání, jsou nesrovnatelně horší...

\section{Obec (město)}

Práce pro obec je jen pokračováním prospěšných (neziskových) činností, kterými se podnikatelé snaží pomáhat lidem: „Když obec něco ode mě potřebuje, tak vycházíme vstřic a děláme za minimum. Žijeme tady a chceme, aby to tady bylo hezké.“ (RI). Pomáhat si je i v tomto prípadě vzájemně výhodné... „No dělala jsem několik výstav $v$ místní špejcharovně, takže prispívám ke kulturnímu životu obce. Výstavy měly velký úspěch - přišlo nám $a z ̌$ dvě stě lidí. Obec toto uvítala velice pozitivně $a$ podporovala tyto moje činnosti.“ (R7) ... někdy se tak pomáhá hlavně v místech, ke kterým má podnikatel vztah založený na majetku: ,jihočeské prostředí mám opravdu rád a snažím se $k$ jeho rozvoji prispivat hodně. Podporujeme zejména obce, ve kterých máme své pozemky a majetek - Němčice $u$ Volyně, Kraselov, Hodějov. Těmto obcím dávám $k$ dispozici prostory i mechanizaci, podle toho co potřebují. Záleží mi na správném soužití.“ (R5). Prospěch ale nikdy není na prvním místě - cílem práce pro obec není zisk, ale budování dobrých vztahů: „Opravujeme kapličky a památky pro obec. Pro obec vždy uděláme lepší, $v$ některých př́padech až symbolickou cenu. Nebo si sem mistní děti chodí vyzkoušet

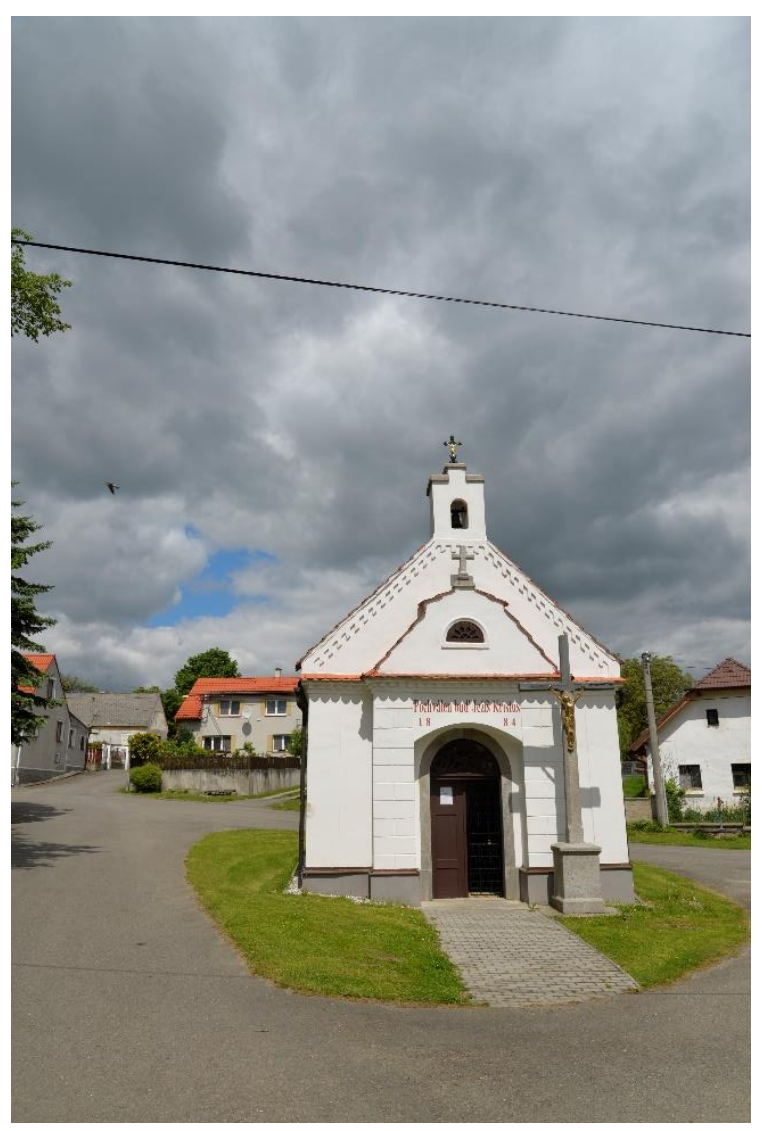
výrobu, mám je tu jedenkrát týdně. Je to jejich zájem, který já ráda podporuju.“ (R8).

Někdy se ale vloudí pochybnosti, zda pro dobré vztahy s lidmi není potřeba být tak trochu neviditelný: „, $V$ malém podnikání je to velice prrijemné, obec mě podporovala a to jak instituce, tak i občané. Otázka je, jak by to bylo, kdybych podnikala ve velkém. Nevím, jak by zafungovala lidská závist ... Já jsem měla činnost, kterou jsem nikdy nikoho neobtěžovala a kterou jsem nikdy nemohla zbohatnout. Proto ze mě byli sousedé nadšení a já mám jen ty nejlepší zkušenosti.“ (R7). A kromě pochybností někde nepříznivé vztahy skutečně existuji: „Od obce nic dobrého nečekám, každý závidí každému, nic tu nefunguje, obec hází klacky pod nohy. Současná starostka na to nemá kapacitu, bohužel.“ (R/9).

Je to škoda, protože drobné podnikání do obce může přinést nové příležitosti: „Sám se snažím do Prachatic donést něco, co obyvatelům ještě chybí. Napřiklad to prodejní místo s masem, se zrajicíma komorama. $U$ toho bych si představoval malý bufet, se vším domácím - prdelačku, držkovou polévku.“ (R9). A tyto přiležitosti její život oživují, přivádějí sem návštěvníky a nové podněty či aktivity: „S obcí spolupracujeme, budujeme kulturní i sociální život v obci. Za prostředím, které v obci vytvářime, přišlo již několik chalupárŭu, kteři se netaji tím, že přišli zejména kvưli nám. Tato vesnice, která má sto obyvatel, má otevřenou hospodu téměř nepretržitě a ... má udržovaných několik zvyků - jako je jarní vyhánění dobytka, v létě je každé úterý tanečni."“ (R4). Někdy tak vzniká nová tradice, o kterou se může oprít turistika nebo se na ni navázat další aktivity: „Každou akci, kterou porádáme, tak pořádáme ve spolupráci s obcí. Město Sedlice je vždy partner, máme od nich vždy záštitu. Pořádáme krajkářské slavnosti. Do obce tato událost každé dva roky dostane pět set až osm set lidí. Obec koupila dům v obci na náměstí, který by se měl přeměnit na dům krajky. V př̌zemí 
budou dílny na výuku kurzů a v horním patru budou přednáškové sály.“ (R/4). Ostatně - tradice v sobě má vždy prvek historický, jehož rozvijení může mít i své vlastenecké pozadí: „,..od února 2012 je náš jezdecký klub členem Selské jizdy. Od malička mne to táhlo $k$ vlastenectví a tak mne činnosti spojené $s$ aktivitami Jihočeské Selské jízdy naplňuji. Každoročně se se svými koňmi tak účastníme jejich akcí, které jsou pořádány v obcích Jihočeského kraje, aby pripomněly působivou jihočeskou historii.“ (R/2)

Odkazů na aktivní pomoc obci je ovšem tolik, že se nám sem ani všechny nevejdou...

\section{Místo a péče o ně}

Péče o pěkně vypadající prostředí je také příkladem toho, jak se investovaná práce promění v radost (pro všechny), a toto přijemné, inspirativní prostředí zase podpoří úspěšnost podnikání: „Báječně to funguje. Děti se hrají a prohliži zviŕátka a rodiče mají možnost si nakupovat. Ty zviŕata mám jen kvůli reklamě a spiš do nich jen investuji, asi mi nikdy nic vydělávat nebudou. $O$ žádném placení za prohlídku jsem nikdy nepremýšlel. Opravdu to je jen pro reklamu. Ale dává mi to i radost, pozemek vypadá dobře, vše je rádně vypasené a díky našemu úsili $i$ upravené. Dělá mi radost se na to divat. Pro děti jsem zde udělal i takovou perníkovou chaloupku, kde si mohou hrát. Rodiče je při hraní vyfotí, pak tu fotografii někomu ukážou a rozšiřuji tak naše jméno dále.“ (R2). Tato péče je založena na jasném plánu na zlepšení, jehož cílem je nabídnout př́ijemný zážitek: ,... to chcete všechno udělat podle představ - chodníky, cesty, lidi aby tam byli nějak oddělený, aby si sedli, odpočinuli, aby je lákalo v neděli prijjet, no a s těma dětma se u nás proběhli, nakoupili a spokojeně odešli a př̌ští týden znovu príjeli - takovou nějakou představu mám." (R2). Podnikatelé asi intuitivně chápou, že tzv. „zážitková ekonomika“ přináší značnou přidanou hodnotu té tradiční.

Je to většinou krása, co působí jako katalyzátor a dodává energii - spojuje lidi, kterým na ní záleží a kteří jsou ochotní k ní přispět, celkově tak zlepšuje vztahy: „Obci pomáhám, když něco potřebuje - např. na ples, na hasiče prispívám. Oni mi za to např. pưjčí čerpadlo, nebo hadici. Docela to funguje. I dalším okolním obcím dávám květinové přebytky, aby se mohly vyzdobit. ... Podporuji i další akce z okolí. Pak jsem rád, když ty lidi prijiedou a třeba mi daji za to flašku $\odot$.." (R2). Vzácně se dokonce podnikání rozběhlo hlavně proto, aby se jím tato dobročinnost zaplatila: „Hned po revoluci, jsem si s bratrem založil podnikání na opravu jízdních kol, opravu televizí, zámečničinu, instalaci antén, apod. K tomu jsem dělal ještě předsedu tělovýchovné jednoty. $V$ té době byla ve Štěkni Sokolovna $v$ hrozném stavu, tak abychom tomu pomohli, tak jsem si ji pronajal, dali jsme ji dohromady a začali jsme tam pro-

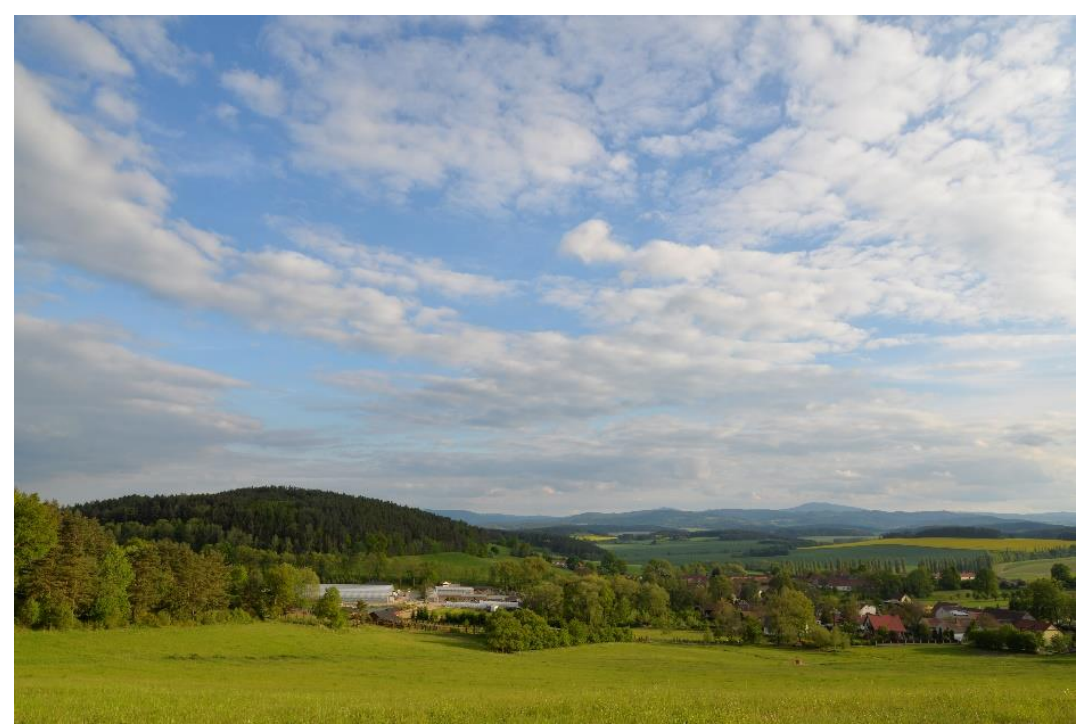
vozovat hospodu." (R20).

\section{Přriroda a prostředí}

Výhodou venkova je krásná příroda hned za humny, a ta je zdrojem odpočinku: „Libí se mi tu svoboda, to, že mohu vyjít $z$ domu a jsem na čistém vzduchu ... ve městě bych měl jen stres.“ (R2); ... někdy je príroda jedním z mnoha dalších zdrojů inspirace, a je opravdu základní potřebou: ,Jsem závislý na všech zdrojích - inspiraci beru z prírody, hudby, a kdybych nejednal s lidmi, tak těžko můžu podnikat.“ (RI6). 
Podnikatelé, kteří jsou zvyklí nezůstat nic dlužni společnosti, také prrírodě oplácejí péčí a šetrným zacházením: „Celý náš podnik je zařazen do ekologického zemědělství, což samo o sobě nese velice prísná pravidla. $V$ lese používáme technologie co nejšetrnějši k životnímu prostředí - vyvážečky, koně..." (R5). Přemýšlejí o postupech a volí nejpříznivější možnosti...: „Opravujeme objekty, přemýšlime nad budováním pastevních areálů, tak aby to mělo i prírodní logiku. Např. jsme snižili míru zornění půdy oproti firmě, která podni-

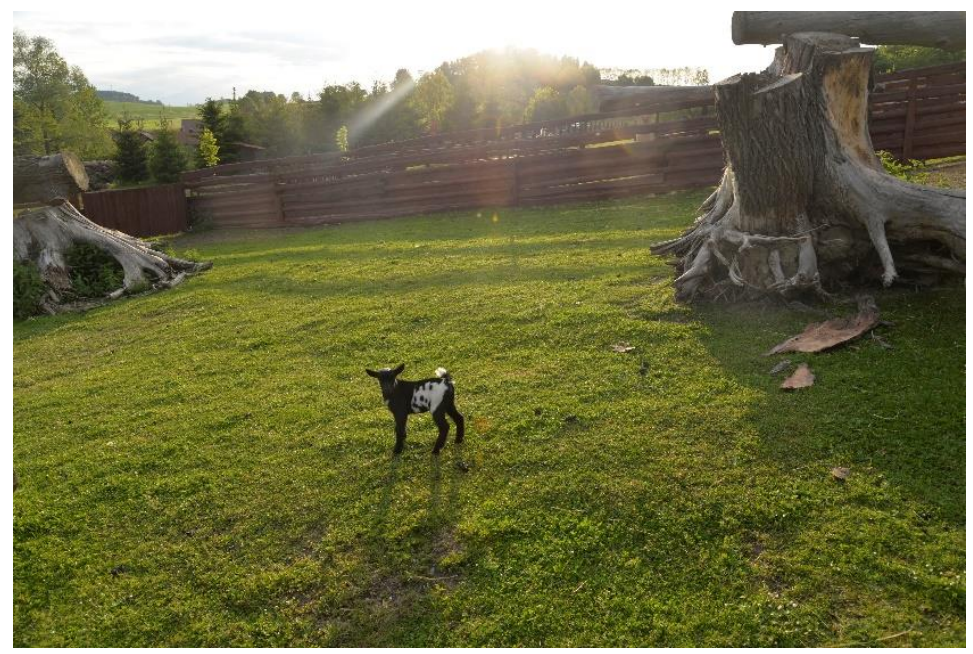
kala na pozemcích před námi. $V$ současnosti tedy máme $20 \%$ zorněné půdy a 80 zatravněné. Co se týče dobytka, tak ten chováme na hluboké podestýlce, a co se týče dalších činností, tak děláme měkkou turistiku s co nejmenším dopadem na životní prostředí a dále prodejem ze dvora se snažíme dělat co nejmenší možnou uhlíkovou stopu potravin před tím, než se dostanou na stůl k zákazníkovi." (R4) ... a tím se posunují dále: „... diky pozemkové úpravě dostanu pozemky okolo svého domu. Chystám se na nich založit nové pastviny na to bych měla získat dotace na zatravňování; dále jsem si nechala dva močály, kde chci vybudovat rybníčky, respektive mokřady - na ně snad taky dostanu dotaci. Mým cílem není dělat zemědělství za účelem čistého zisku - chci ho dělat v souladu s prírodou, aby to tu bylo hezké." (RI2)

K ekologickému hospodaření se hlásí: „,Jsem ekologický zemědělec - nesmím používat žádnou chemii a musím zajistit největši možnou míru spokojenosti zviŕat.“ (R4), ...i když ani to není občas úplně jednoduché a musí překonávat překážky: „Po tom tu máme problematiku získávání ekologické certifikace. Jedná se o složitý proces. Dokonce tak složitý, že jsme $v$ jednu chvili z ekologického zemědělství odešli. Pak se naštěstí poměry změnily a my se opět do ekologického zemědělství vrátili.“ (R4). Ale protože „,o člověka nezabije, to jej posíli“", někdy je touha napravit ekologické křivdy motivem podnikání (funguje to podobně, jako ve výše zmíněném př́padě podnikání nastartovala snaha o zachování Sokolovny): „Statek, kde se kozí farma nachází, patřil od nepaměti rodině ... Bohužel byl za totalitního režimu znárodněn a rodina se musela ze svého rodiště odstěhovat. Otec pracoval léta v Chelčicích na farmě zabývající se produkcí ovoce. Systém a hlavně zbytečné aplikování chemie nebylo v souladu s jeho myšlením a názory. Proto, jakmile padl komunistický režim, rozhodl se získat rodinnou farmu zpět a založit produkci zdravotně nezávadných potravin." (R/5)

Jenomže někdy i tito „otužili“, odolní lidé oni cítí bezmoc nad procesy, které nejde zastavit... „Vadí mi současné zemědělské postupy a to jak ničí krajinu a přrrodu. Splavuje se zem, zemědělské postupy a neustále uvorávání mezí (které jsou zábranou proti erozi a zadržování vody) a zabírání větší a větši části půdy niči ochranu obce, kterou zde vybudovali a chránili naši předci. Proto jsou ted' Cehnice po větším dešti plné bahna. Toto jsou věci, které mi vadí, chtěla bych, aby se velké podniky roztř̌rstily, nebo aby je aspoň někdo donutil dodržovat postupy šetrného zemědělstvi." (R/2) .... tento stav je důsledkem bezohlednosti a touhy po zisku: „....máme tu takové lobby za prodejem pozemků, že to nemá úroveň. Lidé sepisují smlouvy s velkými zemědělskými podniky klidně s výpovědní lhůtou na deset let. Lidé si neuvědomují, jaké to pak má následky, ne jen že s půdou nemohou deset let nic dělat, ale navic je na jejich půdu aplikováno nepřiměřené množství chemie, která má sice okamžitý efekt, ale $v$ dlouhodobém horizontu půdu ničí. Dochází k erozi, $k$ degradaci. Řeči o ochraně půdy jsou jen řeči. Na zemědělské pưdě nenajdete žížalu.“ (RI8).

Naštěstí jsou tu ještě city - vztah $\mathrm{k}$ venkovu má silný emocionální náboj: „Všechno dělám srdcem, tak jak to cítím, myslím, že diky tomu, že jsem vyrůstala na vesnici, tak vím, co je dobře a co je špatně. Proto se starám o biologickou rozmanitost druhů, které u nás žijí, snažím se o zádrž vody v krajině (budováním jezírka), 
sbírám deštovou vodu a tu pak využivám na běžné uživání. Chci udržet přirozený biotop tohoto prostredí. Díky našemu šetrnému hospodaření na pozemcích si už všimáme pozitivních změn - např. se k nám nastěhovali bažanti, srna se srnčaty, zajíci, krepelky.“ (R/2).

\section{Tradice}

V podnikání, o které nám jde, hrají roli nejen o prírodní, ale i kulturní zdroje: „[Závisím] hlavně na přrrodních [zdrojích] - jde mi o sounáležitost s prírodou, o welfare mých koní. Kulturu do svého chovu samozřejmě promítám také, a to $v$ podobě čistě plemenitby, kdy je nutné pátrat $v$ historických pramenech (plemenných knihách) tohoto plemene koně a snažit se najít spojení hřebce a klisny, které dá potomka odpovídajicí kvality a plemenného standardu. Tato práce mě naplňuje." (R/2). Někde starost o tradiční kulturní zvyky podněcuje místní správa: „Paní starostka podporuje nejen komunitní život, ale i ten správný jihočeský vesnický ráz. Nabádá obyvatele $k$ pěstování tradičních odrůd plodin a rostlin na mistních zahrádkách, dokonce nabádá i k chovu tradičních vesnických zviřat.“ (RI2). Jindy je nejdůležitějším hybatelem zájem jednotlivce, který si pak tradiční postupy osvojí a používá je: „Měla jsem pocit, že tento obor i u nás na severu úplně zaniká. $V$ současnosti je to bohužel pravda. Já se tedy snažím o obnovu této tradiční české výroby“ (R8). A protože se takových jedinců občas najde více, vznikají tak společné projekty, které mají širší dosah: „Vyrábíme a prodáváme ručně paličkovanou krajku, zabýváme se pořádáním kurzů pro děti a pro dospělé a sbíráme $a$ archivujeme vše (včetně vzorů dle kterých se paličkovalo prèed sto až sto padesáti lety), co se týká sedlického krajkářství. Vytvářime i nové vzory. Hodně vzorů jsme již měli v obci, ale něco nám nosí i lidi z obce a okolí. To má pro nás nesmírnou hodnotu. Můžeme tak mapovat, jaké vzory byly módní v dané době. Děláme rekonstrukce těchto vzorů a jejich repliky.“ (RI4). Možnost rozvijet tradici nabízejí také napřiklad vzdělávací programy, které je třeba zorganizovat a upravit pro ně místní prostředí: „Na začátku se sešli lidi, kterým nebylo Ihostejné, že Sedlická krajka - tradiční řemeslo pro tuto oblast - skomírá. Chtěli tuto tradici předat $i$ další generaci. $V$ té době sice stále $v$ Sedlici existovala krajkářská škola, ale ta začala po revoluci skomírat. I proto, že musela být plně soběstačná. Kurzovné bylo proto zvýšeno, ale tím se odradilo mnoho žáků. Proto se začaly hledat alternativní cesty, jak tradici zachovat. Krajkářská škola sice již neexistuje, ani nevlastníme původní budovu, ale kurzy krajkářství provozujeme i nadále. Pưvodní budovu byla totiž nutné opravit a její rekonstrukce by byla pro obec v té době neúnosným nákladem. Proto jsme se dohodli se starostou obce, že kurzy se přesunou do místní základní školy a vytvoři se kamenný obchod, kde výrobky budou nabízeny. To se nakonec zdálo jako velice dobré řešení.“ (R/4).

Tradiční výroba má ovšem svůj ekonomický potenciál, třeba v navazujících oblastech. K těm patří zvýšená přitažlivost pro turisty, ale i další př́ležitosti k aktivnímu trávení volného času, třeba $v$ rámci již zmíněných vzdělávacích kurzů pro širší veřejnost. Schopnost prodávat tradiční výrobky př́mo, a práci při jejich výrobě tak ekonomicky zhodnotit, ovšem závisí na tom, že kupující ocení hodnotu těchto „kulturních artefaktư“, která nespočivá $v$ jejich prosté užitečnosti: „Co se týče nákupů krajek, tak nejvice lidí - $i$ presto, že $v$ jižních Čechách

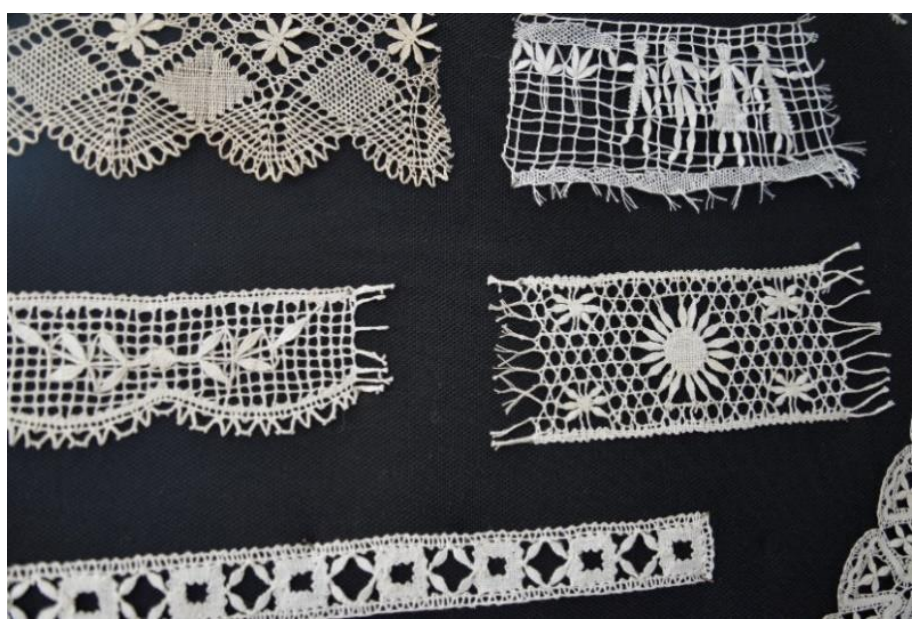
není tolik peněz - je právě $z$ jižních Čech. Lidé zde ještě věři v tradice a chtěji prezentovat ostatním místní výrobky. Chtěji ukázat ostatním, že tohle je naše věc, naše ručně dělaná tradiční věc. Asi i proto, že to má návaznost na náš region. Je to upomínkový předmět. (RI4). Zájem „cizincư“ zde nestačí, příznivý vliv tradičních řemesel by měli ocenit i místní obyvatelé: „O podnikání na vesnici si ovšem myslím, že je v oproti 
městským oblastem tzv. domácí a jako takové by mělo být podporováno nejen obcí, ve kterém se nachází, ale zejména ostatními obyvateli. Ti by si měli uvědomit, že koupí lokálních produktů nepodporují jen samotné podnikatele, ale i ekonomiku kraje a české tradice, které s většinou podnikání na venkově úzce souvisí." (R2). Zdá se tak, že i prostá spotřeba by měla být předmětem výchovného pưsobení.

\section{Podnikatelský étos}

Poctivý přístup podnikatelů ke svému „řemeslu“ i lidem, kterým má sloužit, a vlastně i prostředí, v němž se odehrává, Ize shrnout stručně: „Vycházím lidem vstříc a dělám kvalitně. Mám radost ze spokojených zákazníků.“ (R/3). Je to základ důvěryhodnosti, na které staví i vlastní úspěch: „Když je zákazník spokojený s odvedenou prací, doporuči mě jinam. ... Úspěch vidím ale hlavně v těch spokojených zákaznících..."(RI).

To ovšem není vůbec jednoduché - za poctivostí stojí značné úsilí: „Máme otevřeno neustále, sobota, neděle, svátky. Jen v zimním období máme asi jen do 16:00. Dále pořádáme různé akce na dušičky, Vánoce, Silvestr. Pak máme mnoho akcí pro děti. Navíc se snažíme mít neustále sortiment i mimo sezónu. Ostatní zahradnictví už mají zavřeno a my ještě doděláváme sazenice - nikdy totiž nevíte, co se stane. Přijdou kroupy, prìjde sucho, prijje koza - a zákazník je rád, že má kde sazenice dokoupit.“ (R2). Důležitým faktorem úspěchu je taky zájem o předmět podnikání, osobní vklad s ním související: „Z finančního hlediska ... spiš do toho vrazím peníze. Ale to neni chyba podnikání, to je chyba moje. Nechci dělat výrobu jen proto, abych prodala. Snažím se svou výrobu diversifikovat. Spiše se snažím o exkluzivní výrobu. To zabere hodně času. Jinak je to nedotažené a výroba mě netěši." (R8). Není možné se ale pouze obětovat - ve vztahu k zákazníkovi je třeba taky hájit vlastní zájmy: „Když ke mně príjedou zákazníci, vždy s nima jednám na prímo a oni vybírají srdcem. V̌̌dy je maximálně o zviřeti informuji, řeknu si cenu a na té trvám. Pro mě ten kůn̆ takovou cenu má, a pokud ji ti lidé neakceptuji, tak vím, že si ani toho koně nebudou vážit a měli by se poohlédnout jinde.“ $(R / 2)$.

\section{Cílem je dlouhodobá udržitel-} nost založená na postupném budování dưvěry: ,Já podnikám tak, že když svého zákazníka potkám za pět nebo deset let, tak chci mít čisté svědomí a nebát se mu podivat do oči. Takže pro mě je důležité podnikat poctivě. ... Tak jak chci, aby se lidé chovali ke mně, tak se chovám já k nim. Tohle má každý v sobě." (RI). Pověst podnikatele je i důležitou obchodní reklamou „....buduji si tak [nízkými cenami] dobré renomé mezi zákazníky a vím, že se mi znovu zákazník vrátí. To, že si to lidé

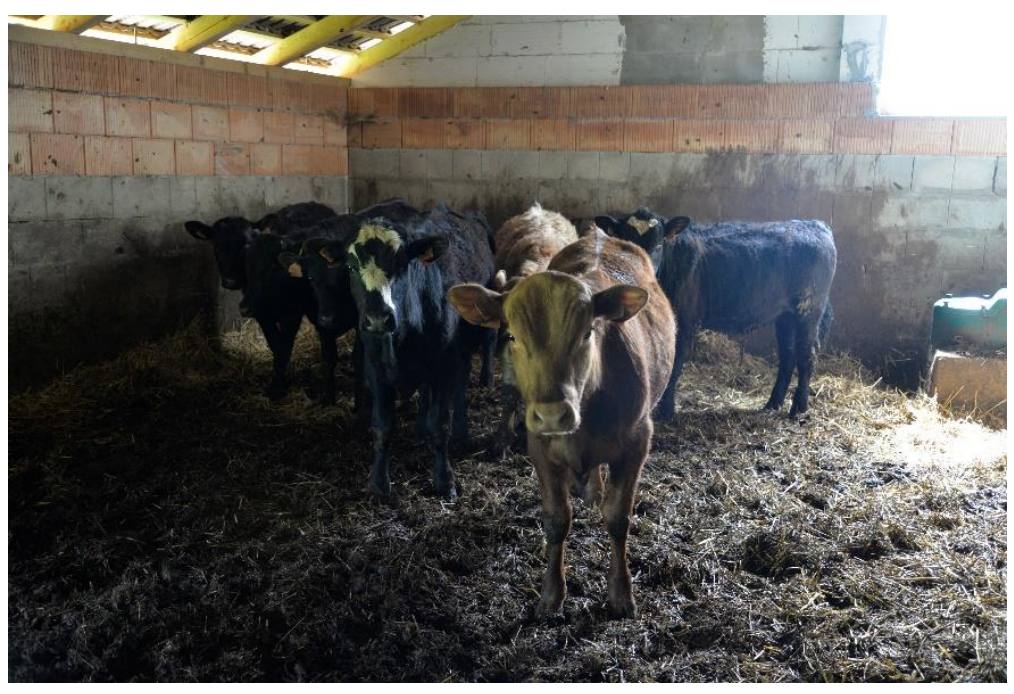
mezi sebou řeknou, je pro mě ta největši reklama. Tímto způsobem jsme ovládly nejen Blatenský trh, ale už i Strakonický a mnoho dalších měst.“ (R3). Zde ještě hraje roli tzv. stavovská čest: „,V dnešní době mnoho tzv. kovářu dělá práci z polotovarů. Podkovu, místo, aby si jí sami ukovali, si koupí a jen upraví. Díky tomu pak dělá - $i$ když na úkor kvality - tuto práci. Já nepouživám žádné kovářské či zámečnické polotovary, snažím se dělat práci precizně a kvalitně. Mým cilem je spokojený zákazník." (R/6).

Kromě odpovědnosti za kvalitu... „Ručim zákazníkům za kvalitu prodávaných výrobků.“ (R4) ...je třeba udržovat i dobré, trvalé vztahy se zákazníky: „... prodej př́mo zákazníkovi důležitý a jsem rád, že mám se všemi tak přátelský vztah. Určitě je to ale také tím, že mě v zahradnictví mohou potkat při každé přiležitosti, 
prohodí se mnou pár slov a myslím, že pak mají pocit, že je o ně dobře postaráno.“ (R2). Komunikace s nimi poskytuje i důležitou zpětnou vazbu: „,... dále je nutné neustále investovat, aby bylo možné posouvat podnik stále dál a reagovat na potřeby zákazníka. Komunikace se zákazníky je totiž kličová. Je nutné naslouchat a objevit, co chtěji a vyjít jim vstříc - at' už je to druh piva, nebo touha po čerstvě upečeném masu na grilu.“ (R6).

Základním krédem je potřeba věřit sám sobě, a hlavně vydržet! ,Já jsem začala podnikat, když byla ekonomická situace snad nejhorší a každý nás od podnikání odrazoval. Nikdo nevěřil, že přežiju první dva měsice, pak rok. Pak zase řikali, že neprežiju druhý rok, pak třetí. Podnikám už sedmým rokem. $V$ tomhle je důležité nekoukat na ty druhé, koukat sama na sebe.“ (R3).

\section{Etika}

Dlouhodobé „přežiti“" podniku není vůbec samožrejmé - společenské prostředí přeje nepoctivcům: „V současnosti se ale opravdu nevyplatí chovat nic. Multimilionáři jsou ti, co sbíraji dotace. Bohužel, tohle je ted” stav našeho zemědělství a proto je tu tak obrovský tlak na majitele pozemků. Při tom tihle zemědělci, co všechnu půdu „sbíraji“ nemaji žádný areál, žádnou techniku. Mají jen tři kravičky, aby splnili povinnost, sklidí pozemky dvakrát do roka, prodají seno a seberou dotaci. ... Já chci a dělám zemědělství poctivě, nehrabu dotace.“ (R9). Být poctivý - kromě toho že je to náročné - je i značně riskantní: „Moje podnikání je postaveno na obrovském riziku. Mohu samozřejmě jit do těch dotací a dělat to ,špatně“ jako všichni ostatní. Ale já bych rád dělal zemědělství poctivě. Pokud mě okolnosti donutí zrušit mléčnou výrobu, tak vím, že už to ale nikdy neobnovím, že to bude konec.“ (R9). Prostředí pro podnikání je zkrátka nespravedlivě nastavené - naši podnikatelé ale netěží ze situace jejím zneužíváním: „Podporu nepotřebuji, protože věrím, že na co si nevydělám, to nemám mít. Navíc nechci být vázaný. Samotné dotace jsou v současnosti špatně nastavené. Všichni jedou na dotace a zemědělství upadá.“ (RI6). Poctivost je totiž i cestou ke kvalitě: ,„á bych se bez dotaci snažil udržet, mám nejvyšši kvalitu mléka a na to bych spoléhal. Navíc vím, že věci dělám tak jak se to $v$ zemědělství dělat má." (R/9)

A právě kvalitu výrobku považují podnikatelé za nejdůležitější princip své práce - musí se o ni opravdu snažit (a doufají, že toto úsilí ocení i zákazník): „Za svůj etický standard považuji to, že nepustím špatný výrobek. Chci, aby zákazník dostal opravdu to nejlepší zboží, na které mohu být pyšná.“ (R8). Kvalita se má spravedlivě promítnout i do ceny výrobku: „Cenová politika je můj etický standard, nikdy bych nechtěl vydělat peníze na zákazníkovi za službu, která tak naceněná nemá být. To mi prijide nefér vưči normálním lidem.“ (R/6). Starostí o kvalitu se navíc předchází problémům, které vznikají, když se o ni nedbá: „Protože jedeme na kvalitu, nemáme problémy, nemáme reklamace žádné, nemáme problémy se zákazníky." (RI). Tento př́stup se promítá i do procesu výroby - kvalita znamená také, že nejsou drancovány zdroje výroby: „Děláme vše na kvalitu, i když v malém. Nechci zatěžovat dobytek nadměrným dojením. Vím, že by to dlouho pak nevydržely, proto se snažím s dojnicemi pracovat co nejrozumněji a nikdy ne na úkor jejich welfare. Poslední zviřre co jsem dával na jatky, jsem měl od r. 200I, měla devět telat. Dával jsem ji na jatky jen proto, že už nemohla zabřeznout.“ (R/9). V neposlední řadě se kvalita spojuje s místními zdroji a může být nastavena dokonce jako určitý projev vlastenectví: „Kvalita je naším etickým standardem, dále se snažíme brát suroviny českého pưvodu i na úkor méně výhodné ceny.“ (R20)

Skoro to vypadá, že zde jde o nemateriální hodnoty: „Mám radost ze spokojených zákazníků a mám radost, že není nouze o práci. Peníze pro mě nejsou všechno. Jsem spokojený, když práci odvedu dle svých představ, dostanu zaplaceno a zákazník je spokojený.“ (R/6). Tyto hodnoty se netýkají pouze samotné ekonomické činnosti, důležité jsou i všechny její přírodní a společenské souvislosti: „Mým životním krédem je žít pro prírodu a chovat se tak, abychom přrrodní bohatství uchovali pro naše děti a generace po nich. Je mi jedno, zda umřu bohatá, nebo chudá, nejsem materialista. Věřím, že majetek se má udržovat a zhodnocovat tak, aby dalši generace mohla navázat na vaši činnost, ale rozhodně si nemyslím, že je moudré na majetku přiliš Ipět - do hrobu si ho totiž neodneseme“ (R/2) 


\section{Vzdělání a svět práce}

Tradiční postupy, při kterých se využívá všeho, co nabízí venkovská krajina, nebo se přímo pracuje s prírodními materiály, mají nejenom význam ekonomický. Dokonce jako zdroj obživy fungují stále méně - dnes jsou snadnější cesty, jak se uživit, než chovat koně, ručně vyrábět šperky či dřevěné hračky, nebo provozovat kovářskou dílnu. Bylo by ale škoda zcela ztratit řemeslnou zručnost a veškeré znalosti, které se váží k procesu „kultivace“ toho, co pochází z přírody. Už proto, že bychom pak žili ve stále abstraktnějším, umělém světě. Techniky, při kterých si člověk může sám osahat materiál, rozhodnout o jeho novém účelu, a dát mu konečný tvar (nebo jinak uskutečnit svou myšlenku), nemusí ale být zapomenuty, mohou naopak získat nový význam - ve vzdělávání. Jejich prostřednictvím se pěstují důležité vlastnosti (napřílad trpělivost, schopnost pozorovat, poznávat a využívat přirozené procesy), dovednosti (související s kreativitou a schopností uvést nápady do života); rozvijí se také morální stránka osobnosti (člověk si uvědomí zvláštní hodnotu přírodních zdrojů a tradičních postupů, jejich symbolický význam pro člověka). Protože přiležitosti k takovým činnostem jsou dnes poměrně vzácné, je třeba ty existující využít - pro mimoškolní činnosti, nebo jako součást nabídky volnočasových aktivit pro dospělé. Zapojením tradičních postupů do metabolismu současné společnosti, jejich přesměrováním pro potřeby dnešního člověka - což jim navrátí život, byt'v jiné podobě - vznikají nové ekonomické přiležitosti, které mohou mít zásadní význam pro oživení odlehlých venkovských oblastí.

Tyto dva konce (ekonomický a vzdělávaci) se mohou s výhodou spojit: vzdělávací rozměr se stane cílem, a zároveň nenásilnou složkou ekonomické činnosti, proniká všemi jejími součástmi. Ve vzdělávání pak „o něco jde“: jeho smyslem je rozvinout umění „žít z mála“, při vzájemné (materiálni) pomoci. Lidé na venkově pak nacházejí práci, zůstávají zde a pečují o své prostředí (jehož cenu si začínají uvědomovat), využívají - a oceňují - místní zdroje. Samotné aktivity jsou tvořivé a spojují v sobě prvky přírodního a kulturního dědictví, které se rozvijí v současném kontextu; mohou tak být základem hlubšího poznání regionu z hlediska jeho tradic. To vše poskytuje škálu možností, jak dělat zajímavou a smysluplnou práci, zároveň pomáhat své komunitě, a vychovávat schopné a poctivé občany. Zdá se, že význam řemesIné práce pro vzdělávání není doceněn...

\section{Autentické učení}

... přičemž dnešní děti žijí velmi často $v$,neskutečném“, virtuálním světě. Nedostatek podnětů, které by se jich přímo týkaly - měly schopnost ovlivnit jejich smysly a pocity, vztahy, predstavy o budoucnosti - může vést $k$ tomu, že se z nich stanou ,nezúčastnění pozorovatelé“ životního dění. Turisté, kteři jsou na Zemi pouze na návštěvě a mají za úkol si tento dočasný a celkově nezávazný pobyt užít. $\vee$ současném, poněkud abstraktním vzdělávacím systému jsou

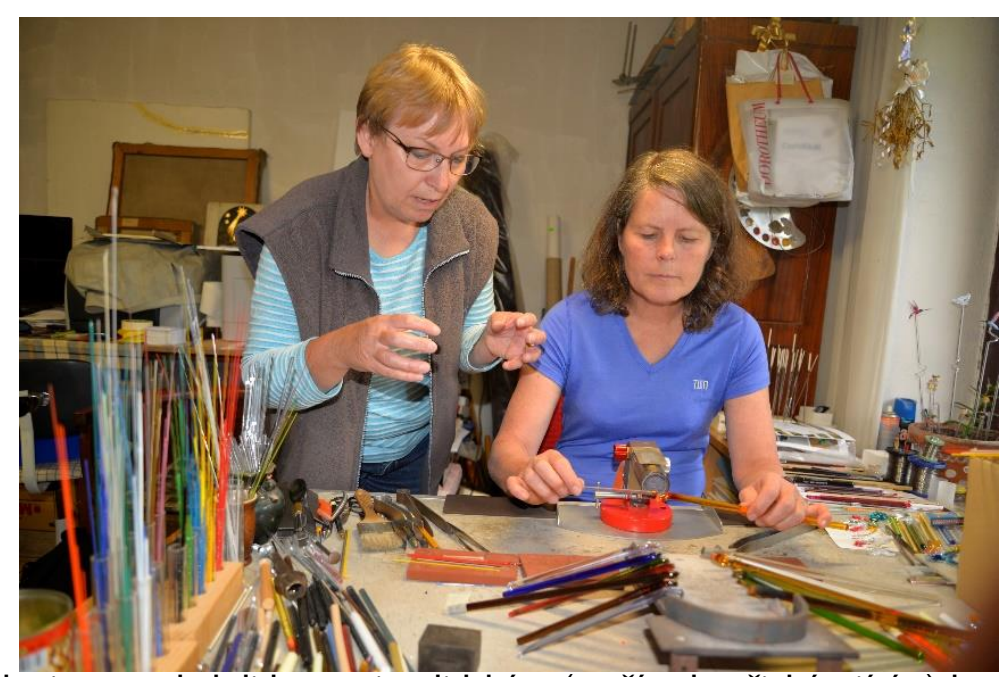
děti vyvázány z přímých vazeb, které by je poutaly $\mathrm{k}$ lidem, mimolidským (z přírody přicházejícím) bytostem, místu a kultuře $v$ jejím historickém kontextu. Hrozí nebezpečí, že lidé, kteří z nich vyrostou, nebudou schopni pochopit vážnost životních i společenských událostí, a nebudou též ochotni k nim přispět vlastním, často bolestným rozhodnutím s osobními důsledky. Pokud se nám zdá, že kolem sebe máme takové lidi - zvyklé na pohodlí a vyžadující toto pohodlí jako politický program budoucnosti, o 
který se ale musí zasadit někdo jiný - Ize kořeny tohoto stavu spatřovat $v$ nevyváženém výchovném a vzdělávacím systému. Jehož primárním cílem je zajištění blahobytu prostřednictvím znalostí, což vede $\mathrm{k}$ jejich hromadění v jakési vykazatelné, pro vlastní prospěch využitelné podobě. Znalosti, jichž je nadbytek a nejsou kriticky poměřovány s tím, co je přesahuje (například obecně platnou morálkou či objektivní pravdou), se ale mohou stát stejným prostředkem manipulace, jako neznalost. S jejich pomocí Ize prosazovat osobní a společenské změny, které nejsou založeny na (cíle)vědomém rozhodnutí.

Pokud ale děti projdou zkušeností, která je formuje, může to být nejen zážitek, ale také „,bod obratu“ $\checkmark$ jejich životě. $V$ dnešním uspěchaném světě takové formativní zkušenosti citelně chybí nám všem, ale dětem nejvíce. Vždyt' kolik mají príležitostí se zamyslet, kdo jsou a kým nebo čím by chtěly být? A pokud takové zkušenosti mají, kolik z nich se odehrává v prrímé konfrontaci se světem, ve kterém jde o vážné věci: například při naplňování základních životních potřeb svých i druhých lidí, ve službě sobě, své rodině a společnosti?

$\checkmark$ této publikaci tak chceme představit možnosti výchovy, která by př́mo souvisela s prací. Tou zde ale nerozumíme jednotvárnou, ubíjející práci, kterou společenská dělba zmechanizovala. Máme na mysli činnost cílevědomou (směřující $k$ rozmyšlenému, předem stanovenému cíli), která je založena $v$ zájmu o pracovní proces i její výsledek, zahrnuje vytrvalost, schopnost překonat překážky, touhu neustále se učit. Uvažujeme o práci „,místně zakotvené“, která využívá zdroje, jež jsou k dispozici v místě, a to šetrně. Která vede $\mathrm{k}$ hospodárnosti a snaze tyto zdroje rozhojnit - zvláště pokud jde o zdroje kulturní nebo lidské. K práci, kterou zde popišeme jako výchovný či vzdělávací prostředek, patří určitá zručnost, mistrovství, které lze nabýt zkušeností, je třeba je ale také předávat dál - jako součást kulturní obnovy a reprodukce. Tato zručnost, stejně jako práce s materiálem a znalost jeho různých podob a vlastností, váže člověka přímo ke zdrojům, jež mu po staletí poskytovaly obživu a blahobyt. Znalost ,původu věci“ $v$ jejich materiální podstatě a přetvořené podobě je podle autorů této publikace jedním ze znaků uvědomělého lidského bytí - podobně jako znalost biologického a historického původu vlastního. Chápeme pak přerušení tohoto př́mého vztahu k prvotním surovinám a materiálům jako další znak vykořeněnosti člověka z jeho světa. Myslíme si, že na uchování či postupnou obnovu těchto původních vztahů by se vzdělávací systém měl mimo jiné zaměřit. Nezvýší tak pravděpodobně „cenu člověka na trhu práce“, ale může zvýšit hodnotu jeho života pro něj samotného - tím, že mu pomůže najít sebe sama mezi, či spišse uprostřed lidských vztahů a symbolů. A nakonec toto sebeuvědomění může člověku pomoci zapojit veškeré silly, aby dosáhl svých životních cílů. Pokud jsou tyto cíle svázány s (místni) ekonomikou, takto nabytá zkušenost se samozřejmě neztratí ani v praktické rovině.

\section{Zkušenost z procesu „výroby“}

Každý z nás měl už někdy ve vlastnictví ručně vyrobený předmět. Někdy méně dokonalý, než jeho prefabrikované dvojče - většinou docela neobratně dává najevo svou původnost. Svými (některými) rysy odkazuje na to, čemu se dnes rríká „,príběh“ - je v něm patrné úsilí toho, kdo jej vytvořil, jeho nápad nebo tvrdá práce a čas, které předmětu věnoval. Jakoby se část osobnosti tohoto tvưrce vtiskla do předmětu, a my ji pak drželi spolu s jeho účelovou podobou v ruce. Často nás to nutí, abychom $s$ takovými předměty nakládali jinak, než $s$,obyčejnými“: ne čistě účelově. Při pohledu na výrobek či jeho používání se zamýšlíme nad člověkem, který svưj čas věnoval vlastně nám, aby nám jej předal; nad cílem jeho snažení a surovinami, které byly jeho úsilím přetaveny do konečné podoby; nad vším, s čím se během procesu výroby setkával. Nekonáme již každodenní činnost bezmyšlenkovitě a jakoby $v$ opuštěnosti od lidského společenství: hmatatelně jsme se stali součástí řetězu vzájemné pomoci a předávání. I když je toto sdílení podmíněno poněkud abstraktními finančními transakcemi, nám se najednou ukazuje ve své konkrétní, lidské podobě. 
(Snad) všichni jsme už také něco „ručně“ vytvořili. At’ to již je oběd, který jsme připravili rodině či prátelům, nebo dítě, které jsme vychovávali. Někdo si vypěstoval léčivé byliny na zahrádce, jiný je nasbíral v lese poté, co si našel jejich „správnou podobu“ v atlasu rostlin. Víme tak, že proces takové „výroby“ je nejistý (může se nám neurodit nebo omylem natrháme něco jedovatého) a vyžaduje mnohé znalosti, které se ve škole neučí (především postupy při zvládání těchto „běžných“ činností se značně liší od vědeckého přístupu, který je základem školního poznáni). Možná, pokud jsme byli zvláště dobří žáci, jsme se najednou cítili ztraceni tváří v tvář vlastnímu dítěti či jinému „živlu“, který př́i takové činnosti nečekaně vstoupil do našeho života a ted' jej máme na starosti. Ukázalo se, že v těchto případech se musí „plánovat“ podle trochu jiných (než ve škole naučených) zásad, a nám by se najednou hodily spíše zkušenosti záškoláka. Jakoby v našem vzdělání zela fatální díra.

\section{Autenticita v místním podnikání}

Zkušenost s ,autentickým“ původem a podstatou věcí, i se vzájemností při jejich předávání, si někteři z nás chtěji zažít i při nákupu nových předmětů či služeb. Touha vymanit se z velkého společenského koloběhu, a dát vlastní spotřebě „,lidskou dimenzi“, je společná stále většímu množství spotřebitelů a má tak i svůj ekonomický význam. $\vee$ rozvinutých zemích světa se projevuje jistá prresycenost prefabrikovanými, anonymními výrobky, a navrch získává touha po „př́běhu“, který se skrývá za jejich vznikem. Protože kvalita a zvláštnost hrají v konkurenčním boji významnou roli, u některých kupujících takové předměty začínají vítězit. Jsou to většinou lidé, kteří stojí o aktivní využití svého času, jsou individualističtí, nezávislí, informovaní, „bez hranic“. Životní styl, který vedou, jim dává určitou nálepku, sociální status jsou to ti, kteří si váží vlastní jedinečnosti a mají vnitřní zájem na věcech či událostech (Boyle, 2006).

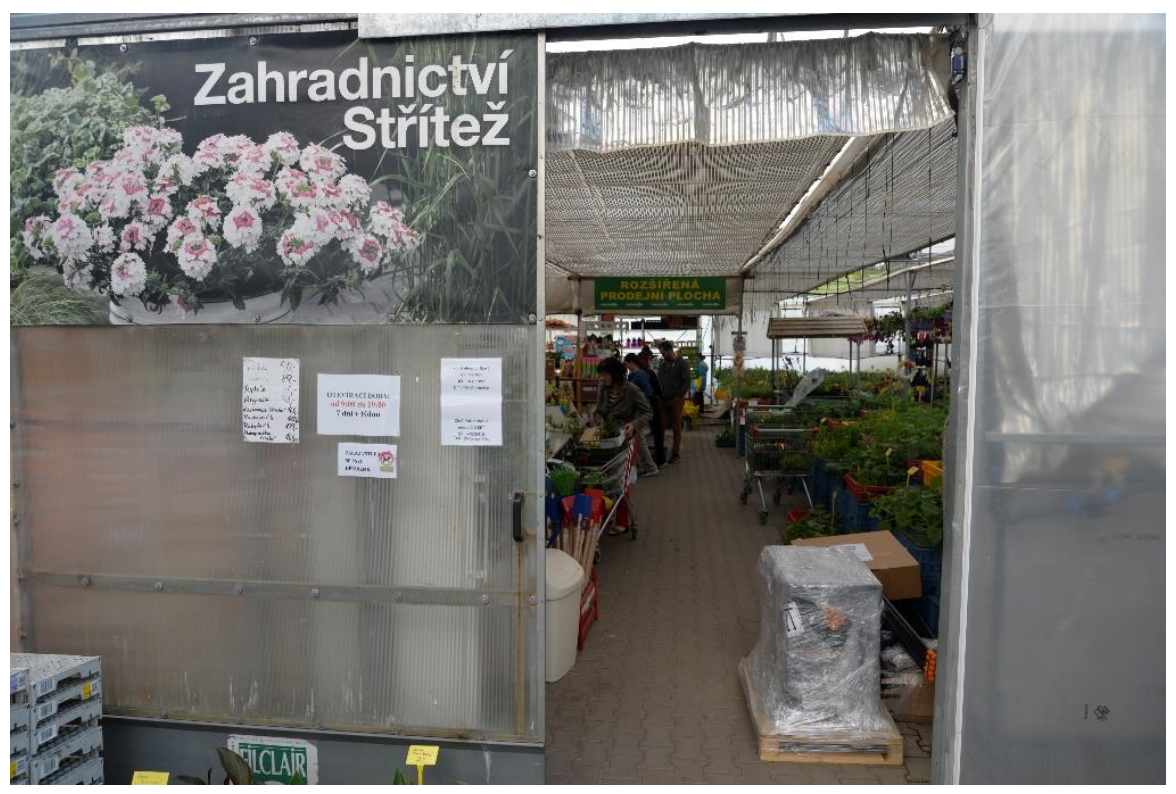
Výrobky jsou jim zdrojem vlastní image, do jisté míry odpovídají na otázku: kdo jsem, jaký mám vztah ke světu, co chci být (Gilmore, Pine, 2007). Takový druh spotřeby je založen na jakémsi vnitřním „souzněni“ mezi tím, kdo spotřební předměty či služby produkuje a kupujícím; jak jsme viděli (a dále uvidíme), o podnikatele, kteř́ jsou naladěni na tuto ,autenticitu“, není nouze. Základem toho, že tato ekonomika „s lidskou tváŕi“ bude fungovat, je důvěra mezi oběma stranami, jistá víra, že to má smysl, i když tato cesta není zdaleka tak pohodlná či levná, jako cesta mainstreamu - každodenní spotreby, která má pouze uspokojit základní, ovšem do nekonečna rostoucí nároky.

\section{Kompetence}

Viděli jsme, že uživit se samostatně vlastním podnikáním není vůbec jednoduché. Odměnou je svoboda, odpovědnost za vlastní činy, možnost rozhodovat samostatně o důležitých životních záležitostech. Dělat to ale nemůže každý - i proto, že se takovému životnímu stylu nedostává společenského uznání a existuje mnoho způsobů, jak se živit snadněji. Ti, kdo zkušeností tvrdé, každodenní dřiny bez svátků a dovolených prošli, nás od ní odrazují. Nicméně na tomto přístupu stojí lidské společenství - bez poctivé 
práce vytvářející základní hodnoty se (z dlouhodobého hlediska) společnost neobejde. Jako vychovatelé bychom si práli, aby tento princip platil obecně, děti k němu byly vedeny a později byl ctěn ve všech odvětvích lidské činnosti. Je zárukou samostatného, nezávislého života, na který mǔže být člověk hrdý. Bez něj by výchova byla obtižná - vedla by $\mathrm{k}$ bezzásadovosti, pohodlnosti a hledání snadných, i když často pochybných řešení. Jak ale $k$ takovému př́stupu cilevědomě vychovávat - jaké vlastnosti se osvědčily, a co musí děti umět, aby obstály?

\section{Nadšení pro věc - a vytrvalost}

První podmínkou úspěchu je vědět, co člověk chce. Teprve potom to také může dosáhnout. Životní sen je tak hybnou silou všeho konání a měl by být dosažitelný. Jeho podstatou je sama radost z praktických činností, které máme rádi a musí se konat každodenně - nikoli abstraktní cíl. Tato radost je pochopitelná člověku v každém věku, a pokud je dostatečně hluboká (prohlubující se úsilím), nemizí - může pak být zdrojem

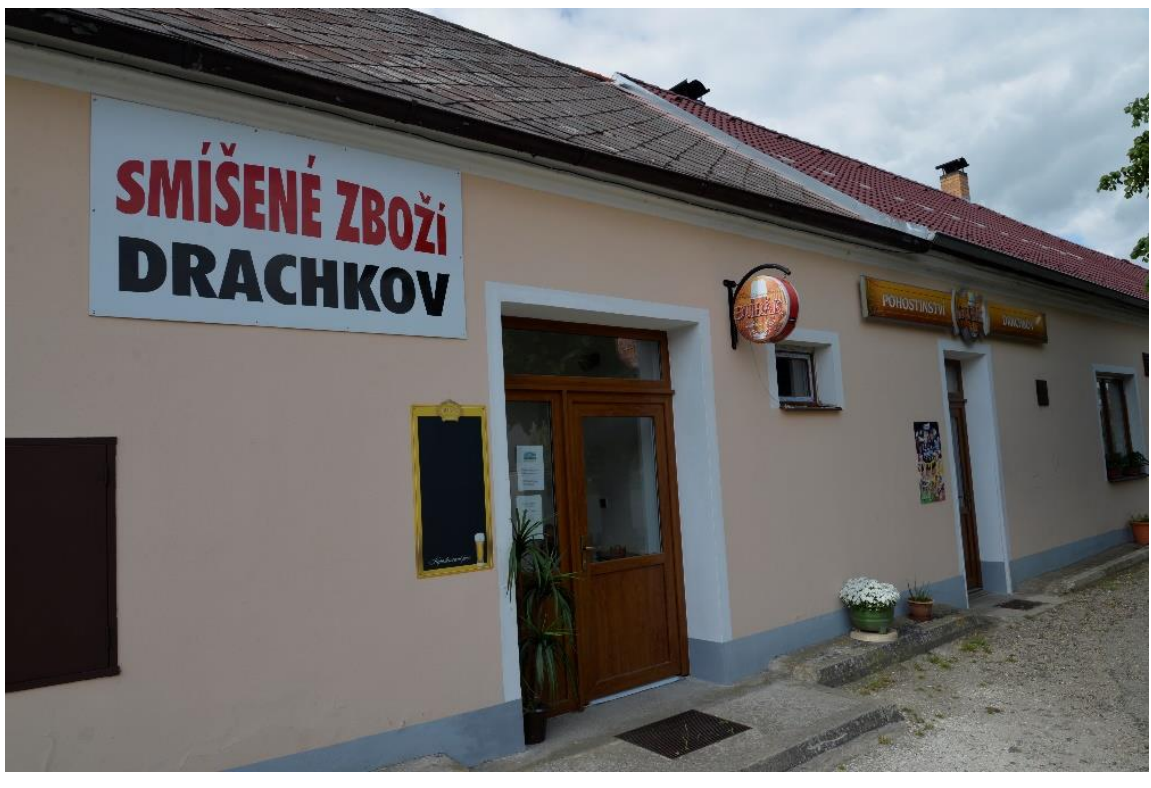
celoživotní spokojenosti.

Nechte děti snít. Avšak sny, které se přetaví do celoživotní náplně, by měly mít dobrý základ: vycházet z poznatků, kultury a sloužit skutečným potřebám lidí.

Do podnikáni jít s určitým nadšením. Nesmíte brát podnikání jen z ekonomického hlediska, musíte to chtít dělat, musí vám to něco i zpětně dávat, a nesmíte na tom moc prodělávat. ( $R 5)$

Já jsem ale veterinár̆, máme tu dvě stě krav a mně dělá radost každé narozené tele. To mě pak práce těší, navíc věřim, že tato práce nejde dělat jen pro obchod. (R5)

Dělejte to, co kdo umí. $A$ věnujte se tomu, věnujte tomu svůj život, ono se to vrátí. Musí vás to bavit, musíte to umět a pak podnikání může být náplní vašeho života. (R7)

Vždy se snažím do všeho dávat svou originální myšlenku. I když někdy si tím zpưsobuji nervy, zda vše zvládnu, podle toho jak jsem si to představila. Dopadlo to ale zatím vždy dobře. Je to spojené s takovým napětím, které mě asi baví a dodává mi energii. Dělám pro zákazníky svatby od A-Z s maximální péči ... (R3)

\section{Návaznost na (rodinnou, místní) tradici}

Snům se nejlépe daří tam, kde dítě vidí vhodný vzor. Nejčastěji to jsou rodiče, nebo místní společenství. Dítě se s nimi ztotožňuje, dokáže si „hrát na“ činnosti, které se kolem něj odehrávají. Představuje si, jak by je samo vykonávalo, vidí jejich výsledky, ale může se domyslet i dlouhodobějších dopadů - radosti 
uživatelů a celkového pokroku. Za praktickým konáním tak vidí i jeho smysl, zasazenost do společenského kontextu. To mu pomáhá hledat $\mathrm{i}$ vlastní místo v životě. Rodinná či místní tradice pak také podporuje vytrvalost - od načatého díla předků se nesluší utíkat při prvních potižích.

Podnikání bylo převzato do tatínka. Táta slibil naší mámě v roce 1969, že na konci života s ním bude pást býky na Šumavě a jelikož táta doposavad splnil všechno, co kdy řekl, tak jsme tady. (R4)

Jedná se o převzaté podnikání mého otce. Začal jsem u otce pracovat, šest měsíců jako řidič, pak jako dispečer, pak na mě postupně přecházely dalši funkce. $V$ současnosti jsem ředitelem firmy. K převzetí přš̌lo pozvolna a bylo to přirozené vyústění situace, neprišlo mi, že by to mělo být jinak. (R2I)

Takže pokud bych měl někomu něco doporučit, tak se o řemeslo opravdu zajímat, stále se vzdělávat a udělat si jméno odborníka. V mém řemeslu je dobré, když pokračujete napřiklad po tátovi, nebo dědovi. (RI6)

Zájemci [o kurzy] z dálky převažují nad blízkým okolím. Je to možná kvůli tomu, že se tato tradice $v$ okolí Blatné a Strakonic stále ještě předává v rodině. $(R / 4)$

\section{Vzájemnost}

Životní náplň si můžeme vybrat jen s ohledem na sebe sama, nebo do ní promítnout svůj vztah k druhým lidem. První případ je daleko více rizikový: při (dílčím) selhání není, kdo by člověka podržel a pomohl začít znovu. Pokud je naše práce „službou lidem“, energie do ní vložená se vždy v nějaké formě vrátí. At' již ve formě radosti z potěšení jiných, jejich podporou, nebo prostým vědomím, že úsilí někomu pomohlo, a nebylo tak ztraceno, ani když nás nedovedlo $k$ úspěchu. Práce jako služba lidem je přístup, který stmeluje společnost, umožňuje, aby jako společnost vůbec fungovala. Vzájemná důvěra podpoři obchodní vztahy; to se ale u nás často ještě neví...

Reklama je to, že když sem lidé prijjedou tak něco zažiji a pak povídají dalším lidem o tom, jak se měli. (R6)

Vím, že je kolikrát lepší podnikat někde, kde vás z lidí nikdo nezná - to samozřejmě na venkově nejde. Kolikrát si lidi dělají naschvály a závidí si. (R2)

Precizní chování Němců mě oslovilo a je mou inspirací - nesrovnatelné chovánís českým svazem Shagya Araba. U Němců neexistuje hrabání si na svém písečku, ale naopak propaguji kolektivní práci, spolupráci mezi chovateli a společnou propagaci. $(R / 2)$

\section{Překonání překážek}

Ani se všemi podněty a př́iznivými okolnostmi nelze vážné životní poslání naplňovat, pokud člověk není vytrvalý. Schopnost překonávat překážky není spojena jen s touhou dosáhnout cíle, ale i s vlastní odolností, schopností čelit překážkám anebo nepřízni. To je vlastnost, kterou je možno - a záhodno systematicky pěstovat, protože se bude hodit v kterémkoli povolání i v osobním životě. Odolnost je druhou stranou úspěchu, bez ní by jej nebylo možno dosáhnout, ale také je konečný úspěch odměnou za strázně, které by jinak bylo těžké překonávat. Tento princip je i výchovnou zásadou, která by nám mohla pomoci vytrvalost $v$ dětech pěstovat. Vždyt' přece vytoužené cíle by ani nebyly tak žádoucí, kdyby pro ně nebylo třeba cosi vykonat nebo přetrpět. 
Myslím si, že mé podnikání je více úspěšné, než neúspěšné. Kdybych se ale měl vrátit na začátek a věděl, co vím dnes, tak bych do toho nikdy nešel. (R5)

Když už se proto někdo rozhodne, tak bych radila, aby vydržel. Nikdy se vám investice nevrátí ihned zpátky. Trvá to dlouho, než se začne dařit, tak jak si představujete. (R6)

Vydržet, nevzdávat. Když to budete dělat dobře, tak se výsledky dostaví. Nebát se kontrol, papírů, ustát to. Úspěch se dostaví. (R3)

Já jsem si ale na všechno musel vydělat sám a tak si myslím, že by to tak mělo být. Když mám penize, tak si můžu něco koupit, no a když je nemám, tak holt si to něco nekoupím. Dyt' je to jednoduché. Ani jsem si nikdy nevzal na nic úvěr. (R2)

Každopádně je nutné se připravit, že pokud se do podnikání někdo pustí, bude jen dělat a dělat a platit - $a$ to mluvím o všech druzích podnikání. Budou to jen starosti, papírování a platby. Kdybych měl nyní začít, myslím, že už bych podruhé nezačal. (R2)

Je to stres, napětí a člověk porád čeká, co prijjde. Podnikání je porád něco za něco, vždy jsou tady překážky. (R3)

Vše musite dělat s trpělivostí. (R4)

Libilo by se mi, jako zaměstnanci, že bych přišel domů a tlak by skončil. Jako podnikateli nic takového nepřichází $\checkmark$ úvahu. Nemám stálou pracovní dobu. (R/6)

Práce je to složitá - je to velká dřina. I otec mi to vždy řikal, ale až ted' jsem mu přiznal, že měl pravdu. (RI6) Nevzdávat to, začátky jsou těžké. Pokud děláte něco, co vás baví, pak optimismus nesmí chybět. (R/4)

Základní investice je vysoká a musíte mít nejen techniku, ale hlavně pozemky. Ovlivňuji vás nejen okolní politiky, ale i počasí. Nemáte dovolenou, musíte do práce v sobotu i v neděli. (RI9)

Vytrvat a nechtít zbohatnout hned. Měli jsme pár okamžiků, kdy jsme chtěli zavrít, ale pak přišel nový odběratel a zase se to rozjelo. (R20)

Musíte si to dělat po suým. Nekoukat jak to dělají ostatní. Na začátku mít raději méně než více informací jinak do toho nepůjdou. (R2I)

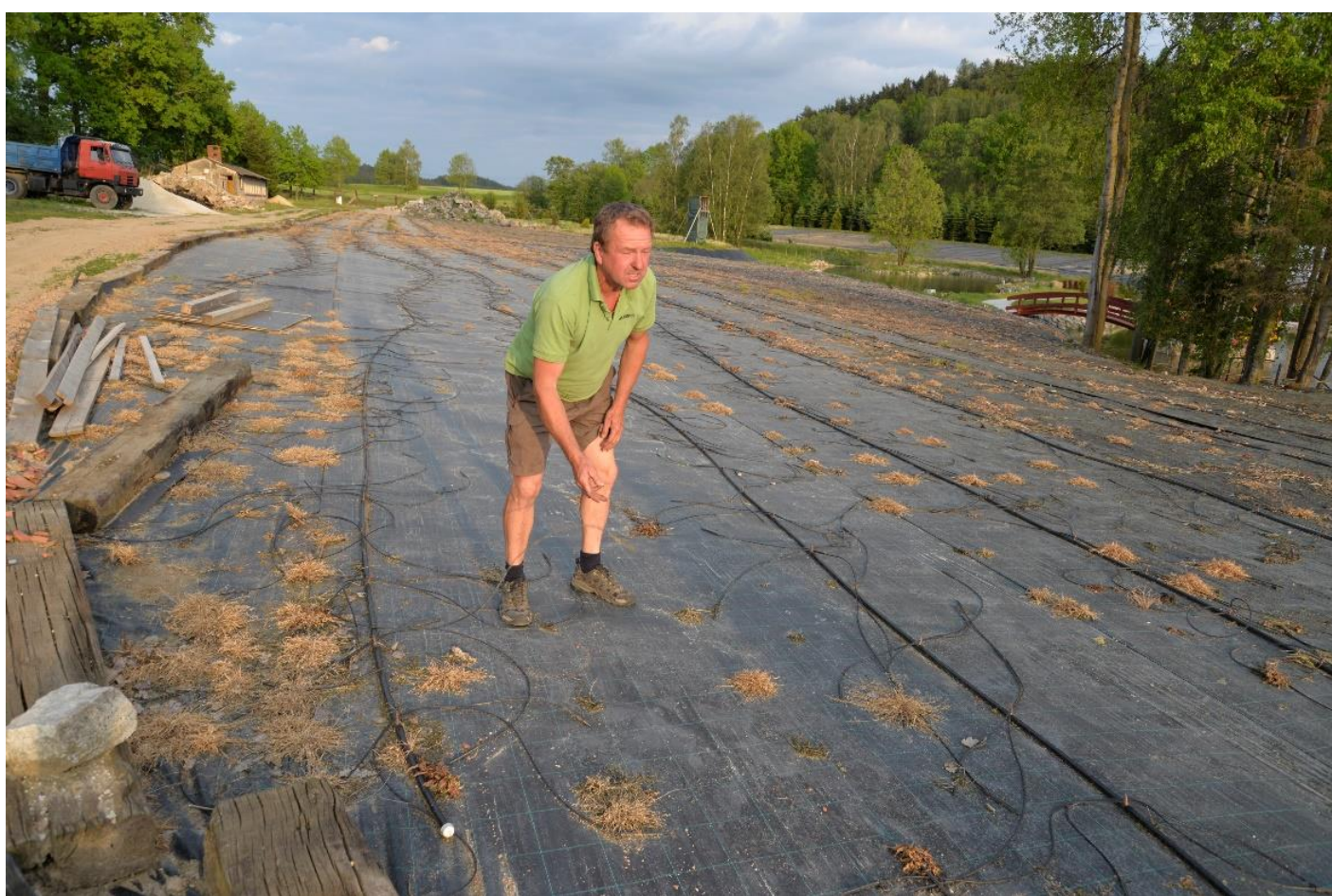




\section{Krása}

Nestačí ovšem být vytrvalý člověk se ve vlastní disciplíně může snadno ztratit, nechat se jí ovládnout. Teprve krásou se naplňuje duše člověka, jejím prostréednictvím se ukazuje i širši smysl toho, co dělá. Krásné prostředí, přírodu teprve můžeme nazvat svým domovem, pro který jsme ochotni ledacos obětovat. V ní pak také nacházíme také odpočinek a útěchu, když se cítíme slabí. Krása je i tmelem dobrých vztahů jejím prostřednictvím si vyjadřujeme vzájemnou úctu...

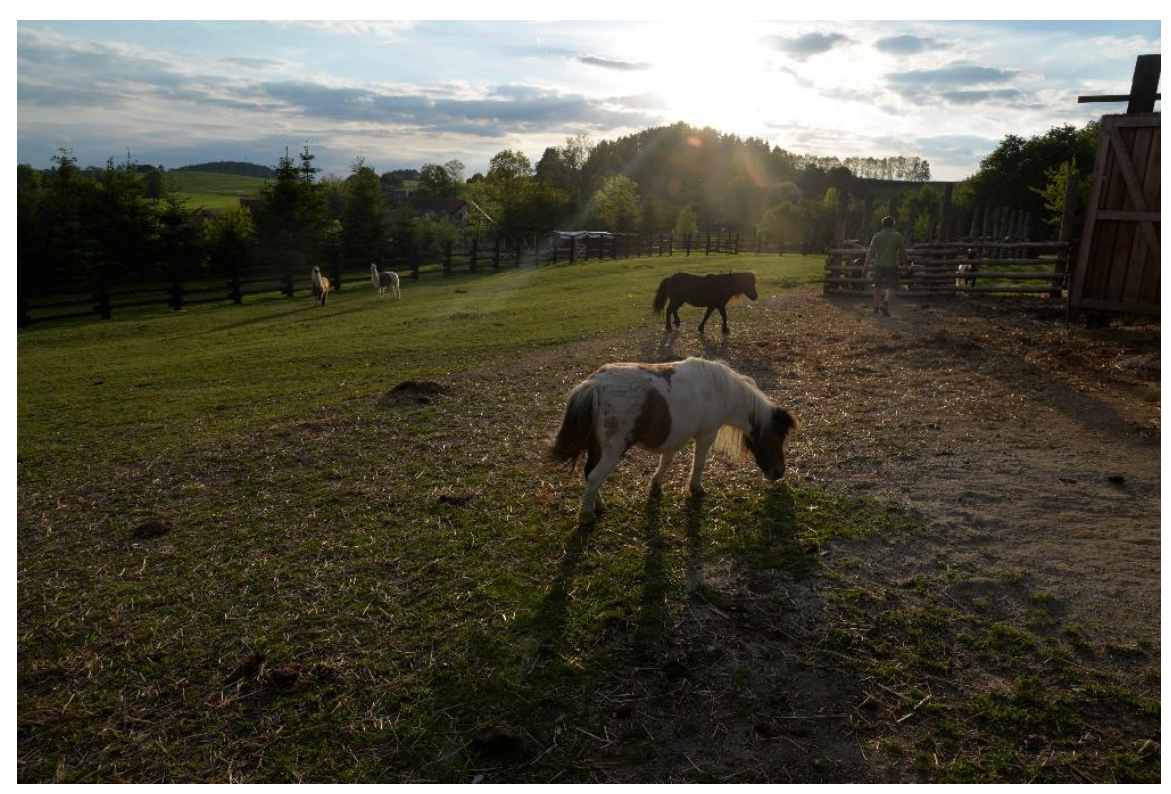

Mé zemědělské podnikání je založeno na tom, že jsme v takhle krásné a čisté krajině, sama se snažím využivat všech zvyků, které jsou uvnitř naší jihočeské společnosti, tak jak je to vůbec možný a myslitelný. (R4).

Inspirují mě stromy, přiroda, rybníky. Vyjedu na kopec a vidím Šumavu, je tady tak hezky. A i když nemám čas, tak se zastavím a rád si sednu na mezičku a rozjímám. (R2).

... a dále mám šanci každé ráno vidět vycházet slunce nad Šumavou. Odtud čerpám energii. ... dobrovolně bych se mista na Šumavě nikdy nevzdala, to by mě museli zabít. (R4)

Nejvice by mi záleželo, aby dobře vypadala naše obec. Dal bych jim kytky, aby obec reprezentovala, když už je tady to zahradnictví. Bohužel jsem se ale setkal s tím, že obecní to pak nechtěji zalévat, nechtěji se o to starat. (R2).

\section{Etické principy}

Podobně jako se zdá být krása jistou zbytečností, „nadstavbou“ nad účelným snažením, tak také dodržování etických zásad zdánlivě k úspěchu přispívat nemusí. Není tomu ale tak: i z čistě obchodního hlediska je etický přístup tím, čeho si zákazník cení. Není to jen spolehlivost, přímé jednání bez postranních taktik, a kvalita výrobku založená na poctivém řemesle, podle čeho si vybírá. Dnes často bere $v$ úvahu i širší souvislosti - to již souvisí s jistou proměnou životního stylu.

Zásadovost si totiž ceníme celospolečensky. Že začíná být „obchodním artiklem“, je vidět i ve vztahu výroby k místním zdrojům, kultuře, společenství. Pokud se ctí povaha a potřeby těchto „zdrojü“, a výrobce nevyvijí svou činnost na jejich úkor, dochází k vzájemnému obohacování. Výroba je pak nejen využiváním, ale spíše kultivací př́rodního či společenského prostředí, a její výsledky mají i mnoho mimoprodukčních funkcí, které jsou (nebo by ve zdravé společnosti měly být) ceněny. Etický vztah ke všemu, z čeho čerpáme užitek, je základem četných politik a výchovných programů - mezinárodně je např́klad oceněn značkou Fair Trade. 
S každým jednám na rovinu, nikoho nepodvádím. (R2)

Vydržet a nezaleknout se. Jděte do toho, nebojte se. Podnikat na venkově má smysl. A podnikat s čistým štítem, nepodnikat na úkor těch druhých. Mít alespoň základní etické standardy. (R/8)

Mám osobní etické standardy, které dodržuji. Snažím se lidem vyjít vstříc a mít lidský přistup. (R2I)

Chtěl bych, aby všichni zemědělci, dělali zemědělství správně, chovali se slušně a nejeli jen na dotacích. (R9)

\section{Kvalita}

Dobrá podstata i zpracování výrobku není jen tím, co má uspokojit zákazníka. V kvalitě výrobku se odráží celý pracovní proces, a v něm pak i přistup jeho výrobce. Pokud pracuje s dobrými materiály, nešidí při jejich zpracování, zná a zvládá řemeslné postupy a má jasnou představu o výsledku, pak nejspiš odvede dobrou práci a bude s ní i sám spokojen. Protože je ale ve velkém ekonomickém systému zakomponováno mnoho ,šidítek“" které dokáží snížit cenu na úkor kvality, výrobci často $\mathrm{k}$ takové poctivé práci nemají mnoho př́ležitostí. $V$ cenové konkurenci se totiž nedokáží prosadit. Jistě ale nechceme, aby se poctivá práce vytratila úplně, a tak je třeba ji všemožně podporovat - tím, že do jejích produktů občas investujeme své peníze. A především také tím, že jí budeme rozumět a učit se všemu, co s ní souvisí.

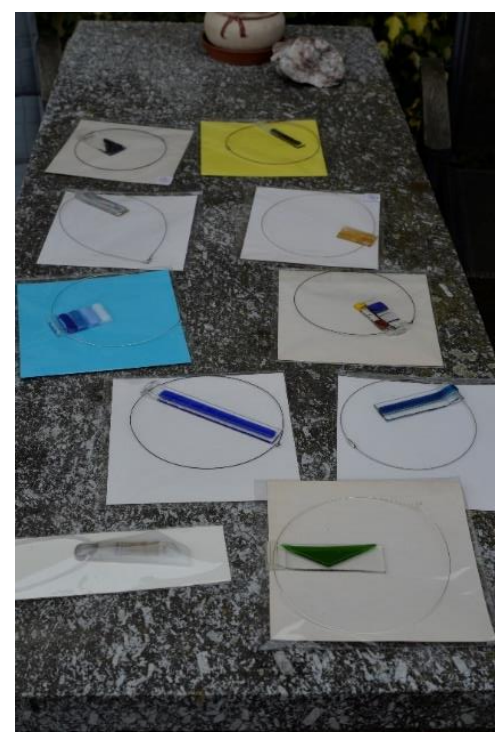

Pro lidi je ale ta výroba samotná velice zajímavá a můžu řict, že pokud mě vidí dělat výrobky, pak lépe ocení mou práci a pochopí i cenu výrobku. (R8)

Je pravda, že to se mnou není někdy lehké, když mám představu, tak očekávám, že ji naplním na sto procent, že nám budou ladit všechny detaily. Nechci řict, že jsem tedy kritická, ale opravdu si potrpím na tom, aby vše vypadalo, tak jak to já mám v hlavě. Než to všechno dáme dohromady, tak z toho mám takové nervy, ale pak když vidím, jak se celek skládá dohromady ... pak už jsem v klidu (R3)

Paličkovaná krajka je drahý produkt. Proto se snažíme, aby zákazník přimo viděl jak náročné je ho vyrobit. Jakmile ví, jak časově náročné je vyrobení malé krajky, pak je ochoten i zaplatit požadovanou cenu. Cena se vypočitá dle času, kolik krajkářka do díla investuje. (RI4)

\section{Pracovní návyky, spolehlivost}

Takovou výuku ale škola často nenabízí. Školní nauky ovládla touha po dosažení „,velké“ konkurenceschopnosti prostřednictvím vzdělání, a tak se nácvik pracovních návyků stává karikaturou (společensky nedoceněného) pracovního procesu, nebo chybí úplně. Autentickou zkušenost provázející pracovní proces, který vychází z potřeby tvořivosti a zručnosti, a je provázen těžkostmi i radostí z výsledku, často musí zprostředkovat rodina. Tuto zkušenost ovšem mohou děti získat od svých rodičů v plné míre pouze tehdy, pokud oni sami se podobnou činností zabývají - takové děti pak u rodinného řemesla mnohdy zůstávají. Těch není mnoho, a tak podnikatel, který hledá šikovné a pracovité učedníky „zvenku“, často vidí, že česká populace je v tomto ohledu do značné míry pracovně ,negramotná“. 
Chodí mi sem kluci ze školy na praxi, chodí vždy na léto. Ty ale neumějí nic a pro mě je to zátěž, protože mi zabere mnoho času je korigovat a hlídat a řkat, co mají dělat. Tyhle děti nejsou schopné jakékoliv samostatné práce. Navíc já pak jen přemýšlím co jim dát za práci, aby nestáli. (RI)

I když lidí mám ted’ mnoho, je opravdu těžké přinutit je, aby začali pracovat jinak, než jak byli zvyklí v minulosti. (R9)

Chce to větší úctu $k$ manuální práci - společnost si musí uvědomit, kdo je pro ni důležitější, je to člověk, který nadoji mléko, nebo člověk, který rozhoduje o penězích, které ještě ke všemu nejsou jeho? (R4)

Vydržet. Vše je na začátku složité. (RI5)

Ještě před několika lety jsme měli čtyřicet pět odběratelů, v nyněǰsi době jich máme zhruba půlku. ... Pekařství je totiž práce $v$ noci, je to náročné. $(R / 0)$

....inspirovat by se měli chutí a energií. Rozhodnout se dle intuice a rychle. (R/2)

\section{Učit se novému}

V žádném povolání člověk nevystačí s tím, co se $\mathrm{v}$ mládí naučil. I kdyby se zabýval tradičním řemeslem, musí se vyrovnat s novým prostředím a nároky lidí, kteří jeho výrobky používají. Obecný názor, že řemeslo anebo podnikání je jednotvárnou činností, je mýtem. To už platí spíš pro práci úředníka, která je o hodně pohodlnější, neposkytuje však bezprostřední radost z náhody a také „užitečnosti“ svého výsledku. Ovšem byrokratické požadavky si i zde vybírají svou daň...

Neustále se snažím hledat inspiraci, jak rozšírit podnikatelské činnosti. (R9)

Č́m by se měli/mohli ostatní podnikatele inspirovat? Dělat poctivě, dělat to dobře a neustále se vzdělávat, zajímat se o novinky, aby byl člověk schopný konkurovat ostatním. (RI)

Ve všech směrech se snažím udržet originalitu a moderní standardy. No jinak se dokonce musím inspirovat, abych pořád věděla, co je v módě, co zákazník bude chtít, co očekává. Denně hledám informace na zahraničních serverech. Obětuji tomu hodně energie. Přijedu v noci domu a ještě tři hodiny pak sedím a hledám na počitači trendy, barevné kombinace, atd. Je to sice práce, ale mě tohle naplňuje. Pak mám radost, že stylem prekenáváme pražské svatby. (R3)

S manželkou jsme hledali inspiraci po celé Evropě - Francie, Německo, Belgie. Po takto získaných zkušenostech jsme se nejprve pustili do chovu ovcí, krav a koz. Hlavním chovným stádem se však brzy stalo to kozí, u kterého pak již farma zůstala. (R/5)

Veškerou zemědělskou produkci jsme se s mužem naučili sami - našimi úspěchy a omyly. Nikdo nám $v$ té době neřekl. Udělali jsme hodně omylü, než jsme se dobrali k tomu správnému postupu. Já jsem sice studovala zemědělskou školu, ale to nás $v$ té době neučili. Můj muž navíc pracoval u dráhy a $k$ zemědělství neměl príliš blízko. Nicméně se přizpuisobil vývoji. (R/8)

Celý den lítám kolem dobytka, ted' bych si večer mohla sednout, ale většinou ještě musím prát, vařit uklizet, ale já místo toho musím sednout $k$ počitači a dělat papíry. Je to pro mě těžké, pořád musím čist nějaké návody, pořád mi chodí nějaké hlášení a musím hlídat termíny. Nejsem nadaná na počitač a o to je to pro mě těžší. $(R / 8)$ 


\section{Kreativita}

Bez nápadu se člověk neobejde $v$ podnikání, ale ani $v$ životě. Vidět věci v nových souvislostech, umět kombinovat různé přistupy a hledat nové možnosti - to jsou schopnosti, bez nichž se nelze vyrovnat se změnou společenskou, technologickou, ale i napřílad generační. Tvořivosti se můžeme naučit prostřednictvím umění, je však př́tomna $v$ každém zamyšlení. A kdo by chtěl bezmyšlenkovitě pracovat, nebo vést život, který je pouhou každo-

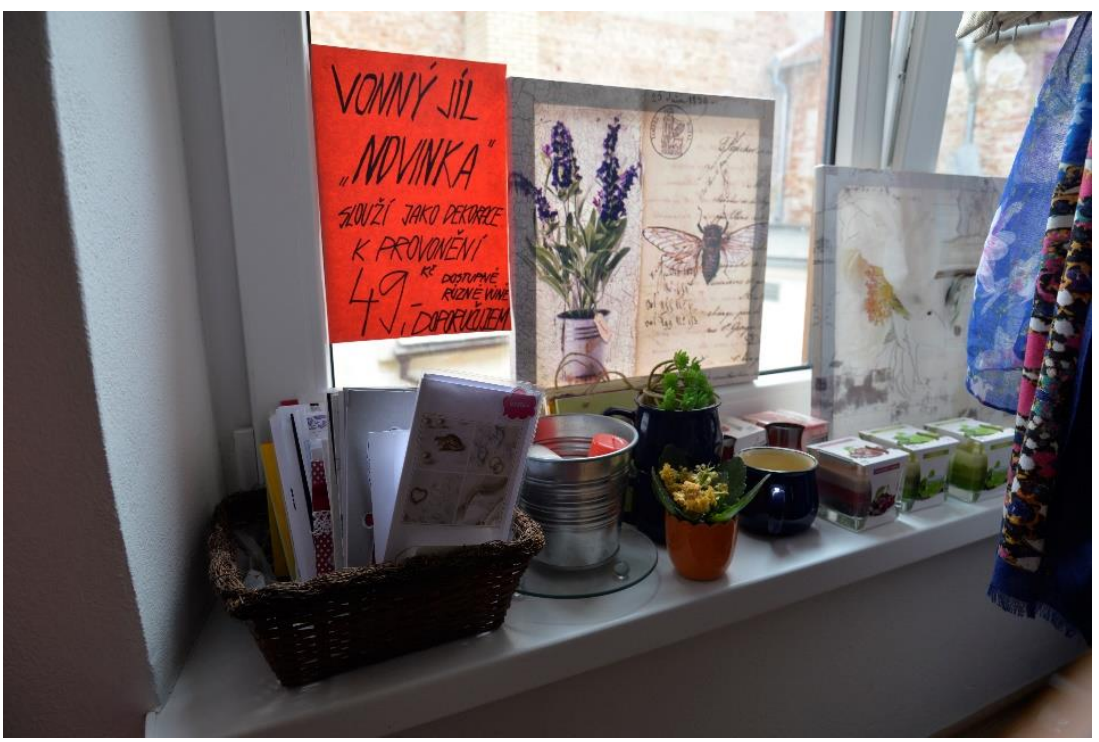
denní rutinou? Není to přijemné, naplňující, a vlastně ani ekonomicky perspektivní...

Proto nás napadlo, že když už stejně do těch Budějovic pojedeme, mohl by to náš řidič na zpáteční cestě vzít přes vesnice, vždy být na určeném místě $v$ určenou dobu, kterou dáme ve známost přes starostu, a ve vesnicích, kde nemají prodejnu, se náš řidič zastaví na deset až patnáct minut a lidem prodá pečivo z auta. ... Zjišt'ujeme, že náš koncept je čím dál tím více žádaný, protože poráa ty obchody na těch vesnicích chybí. (RIO)

Vodňanský kapr - byl jsem inspirován místní kaplí, kde Mikoláš Aleš vyobrazil dva kapry v kopuli. Jen málokdo je ovšem najde. Proto jsem si řekl, že by to byla hezká reklamní strategie pro celé město „najdi si svého kapra“. Turista tak mohl jít do kaple, do restaurace na kapra, nebo k nám do pekárny pro toho pečeného z biskupského chlebíčku. (R/O)

Tady je ale také rozdíl mezi podnikáním a podnikáním. Je něco jiného, když něco prodávát,e a když něco tvořite. Vesnice prímo nabízi tu tvorbu. Ale to už se člověk pomalu nemá kde naučit. Na učilištích se to sice učí, ale $v$ dnešní době výuční list není chlouba a tak každý jde na střední školu a řemeslo tak zaniká, protože na střední škole se toto nenauči. $A$ už vůbec se tam nenaučí podnikat a překonávat prvotní nesnáze a problémy. Na to nejsou mladí lidé absolutně pripraveni. (RIO)

\section{Vztah k místu}

„Zakotvenost“, o kterou tu jde, je vidět na šetrném přístupu ke zdrojům a prostředí. Nevznikla by ale bez vztahu $\mathrm{k}$ místu, které obýváme, kde máme své kořeny. $Z$ něhož čerpáme inspiraci a sílu pokračovat.

Nemohl bych být v paneláku. Mám rád to místo. Lákají mě aktivity, které jsou na venkově možné. (RI3)

... z venkova bych nikdy neutekl. Ted' si tu stěžuju, ale je pravdou, že mě práce baví. (RI6)

Do města bych nešel. Po revoluci jsem dělal spoustu věcí, dělal jsem starostu, byl jsem aktivní i v podnikatelské sféře, pak mě ale zastihla zdravotni přihoda a já jsem zjistil, že nemůžu dělat všechno. Našel jsem si na venkově nového koníčka - jízdu na koni, která mě naplňuje. To by ve městě nešlo. Navíc tu máme ve Štěkni všechno, co potřebujeme $k$ životu - máme tu poštu, hospodu, malý obchůdek. (R20) 


\section{Práce, která má smysl}

Práci potřebujeme k zásobení života základními potřebami, ale i k jeho naplnění smyslem. Vše, co jsme vyjmenovali v předchozích odstavcích, jsou znaky smysluplné práce. Pracovat pro sebe, pro druhé, poctivě, s dobrým výsledkem, v němž se ztělesnily naše představy, nápady a nové impulzy - to je, proč pracujeme. Vytváŕíme si tak vztah k sobě, $k$ druhým lidem, i k světu - to, co v něm vzniká přirozeně, zpracováváme a přetváŕíme. Znovu „interpretujeme“ svůj vztah k přírodě, společnosti $i$ $\mathrm{k}$ sobě samým: a to $\mathrm{v}$ materiální rovině, prostřednictvím výrobku, do něhož jsou vtěleny zkušenosti předchozích generací. Lidé pak mají radost $z$ toho, co vyroste, vznikne nebo je kultivováno jejich prričiněním. $O$ co se mohou podělit s druhými, co přináší radost při přemýšlení, vzniku a užívání. Jak vidíme na příkladech $v$ této publikaci, taková práce pak může být zdrojem obživy i potěšení.

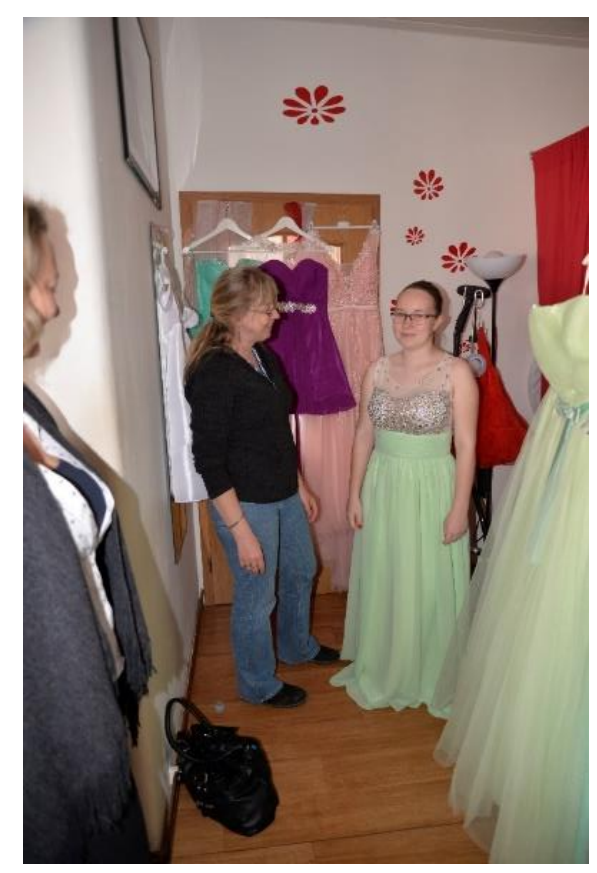

Pozitivní okamžiky jsou ve spokojených zákaznících. Jsem svým pánem - pánem svého času. (R2)

Jsem spokojená, mám svůj čas a jsem spokojená i jako ženská - i mě se daři dělat práci, která je mi koničkem. Je to pro mě dar. (R3)

Pekařina musí být srdcová záležitost. Myslím, si že řemesla maji potenciál, a že nám bude $v$ budoucnu ještě lépe. Podnikat v pekařství ovšem je dřina do toho s tím musíte jít. (R/O)

\section{Životní styl}

Člověk potřebuje ,autentickou zkušenost“ s pracovním procesem a jeho výsledky. Zpočátku jsme se zabývali tím, jak a co lze $z$ takové zkušenosti vytěžit $v$ dospělém věku. $\vee$ tomto období hraje práce roli určité kotvy, prací se potvrzuje místo člověka ve světě - schopnost mu rozumět a využívat toto porozumění pro sebe i pro kultivaci vztahů s druhými lidmi. Hovořili jsme dále o tom, že práce je (či by mohla být) také výborným prostředkem pro pěstování důležitých vlastností, a mít tak význam vzdělávací. Ve výuce se této zkušenosti ovšem nedostává. Je to škoda z hlediska celospolečenského (lidé nejsou připraveni na četné životní situace, které je nezbytně potkaji) i osobního. Schopnosti, které proces přetváření př́rodních materiálů či zdrojů přináší, jsou základem životního „úspěchu“ v mnoha oblastech - všude tam, kde se potkáváme s nevyzpytatelnou „přirozenosti“", kterou musíme začlenit do svého života, kultivovat. At' již to je při trávení volného času, napřiklad pobytem $v$ prírodě, nebo při péči o rodinu.

Manuální dovednosti vycházejí ze snadno pochopitelných postupů a lze je učit i v dětském věku. Děti si osvojí znalosti, které vedou k cíli okamžitě, ne v celoživotním horizontu, a mohou tak zažít uspokojení z vykonané práce. Oproti školním znalostem, které takový úspěch odkládají na neurčito, se odměna $\checkmark$ podobě krásného nebo užitečného výrobku dostaví okamžitě. Autentická zkušenost je ale také potřebou dospělého člověka. Je mnoho povolání, kde pracovník nevidí produkt své práce, a trpí pocitem, že není užitečný. $\mathrm{K}$ manuální práci si pak mnozí z nás jdou odpočinout - mohou pak mít radost $\mathrm{z}$ úsilí, stejně jako z jeho hmatatelného výsledku. Nový životní styl by se tak mohl vyznačovat nejen rozumnou a šetrnou spotřebou, ale také smysluplnou náplní pracovní části života i volnočasových aktivit. 
Mám pocit, že už se lidé v myšlení začínají měnit. Už jim není lhostejné, odkud potraviny pocházejí, chtěji i vidět zviřrata a prostředí ve kterém žijí. (RI5)

Neměnil bych, je to pro mě styl života. Jedenkrát za čtrnáct dní jezdím do Prahy a to mi bohatě stačí. (RI5)

\section{Príležitosti pro výuku}

Jaká je česká populace z hlediska pracovních návyků? Výzkum v této oblasti chybí, ale ve výpovědích podnikatelů občas prosvítá nespokojenost. Děti se k práci nehodí, protože k ní nejsou vedeny. Pracovníků, kteři by měli nejen potřebné schopnosti, ale také vytrvalost a zájem o práci samotnou, je kritický nedostatek. Dovednosti potřebné k práci jsou podceňovány celkově, v obecném povědomí obyvatelstva se často setkáme s názorem, že „poctivou prací se už dnes peníze nevydělávaji'“. Možná $\mathrm{k}$ tomuto názoru někdo dospěl dlouhodobou zkušeností $v$ deformovaném ekonomickém prostředí. Takto ale nevypadá svět, o jehož zachování bychom měli usilovat. Už proto, že by $v$ něm bylo velmi těžké vychovávat další generace, které by za něj nesly odpovědnost.

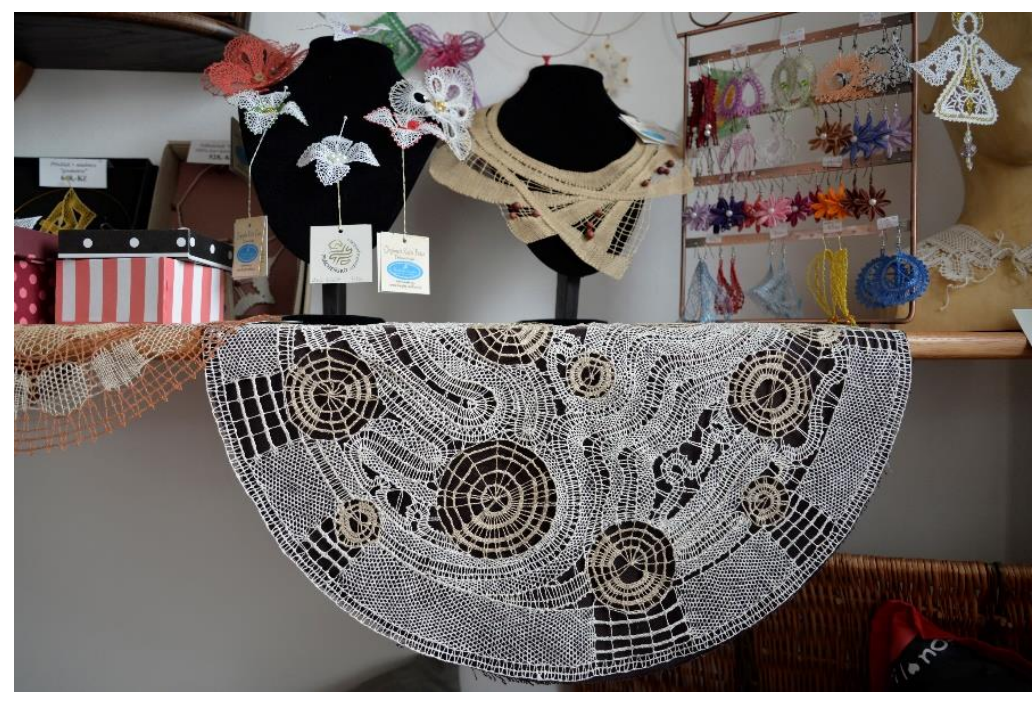

Chápu napřiklad dotace pro děti - podpora jejich vzdělání, workshopy aby se naučili řemeslu - nicméně $i$ $v$ tomto odvětví jsem již narazil. Nabídl jsem učilišti praxi pro učně a byl jsem odmítnut $s$ tím, že odbornou praxi studenti nepotřebují. Ale když jsem se zeptal dětí, tak jsem zjistil, že aby měli na praxi materiál, tak musí chodit do kovošrotu a prosit o železo. Proč někdo tedy nedá penize na takto potřebné věci? (RI6)

$\checkmark$ místě nejen prodáváme, ale hlavně předvádíme, to lidi zajímá nejvíce. Lidé to řemeslo už skoro neznají a tak je výroba krajky opravdu zajímá. Někteři to vidí poprvé v životě. (R/4)

Vyrábíme a prodáváme ručně paličkovanou krajku, zabýváme se pořádáním kurzů pro děti a pro dospělé a sbíráme a archivujeme vše (včetně vzorů dle kterých se paličkovalo před sto až sto padesáti lety) co se týká sedlického krajkářství. Vytvářime i nové vzory. Prodej krajek je pro nás finančně důležitěǰ̌í než pořádání kurzů. Od dětí bereme paušál na kurzy, ale tato částka vyjde spiše jen proplacení materiáli a mzdy lektorky. Pro dospělé také pořádáme kurzy, ale zájem upadá. Je to hlavně kvůli nedostatku času a kvůli vzrůstajícím cenám. Máme samozřejmě zájemce o kurzy z okolí, ale máme také hodně lidí, kteři prijjedou z velké dálky - České Budějovice, Praha. Je to diky tomu, že v jejich okolí není místo, kde by se toto řemeslo mohli naučit. (R/4)

Možná se ani neví, $\mathrm{k}$ čemu by mohla být manuální zručnost v současném ekonomickém systému dobrá. Ovšem „,negramotnost“ české populace v tomto ohledu má již vážné ekonomické, ale pravděpodobně i nepříznivé morální důsledky... Vždyt’ ne všichni máme zájem o povolání, která mají „vyšší společenský status“, jejich vztah ke skutečnosti je ale často nepř́imý a komplikovaný. 
Navíc je extrémně složité najít dobrého zaměstnance - nejsou. Lidé se nechtějí učit a nejsou spolehlivý. U nás i misto prodavačky je bohužel poměrně složité - musi se naučit s květinami, s chemií, a být zodpovědná, být milá $k$ lidem, vstřicná... No a to se opravdu špatně hledá. (R2)

Největší problém je ale sehnat dobré lidi. Nyní pracuje celá rodina a máme 4 zaměstnance. S nimi máme skvělý vztah, jsou to piliře naši firmy, pracuji pro nás přes dvacet let. Nahradit je ale bude těžké. $V$ zemědělstvi se lidem pracovat přiliš nechce a to i přesto, že nabízíme poměrně vysoké platové ohodnocení. No a pak je to vưle pracovat - lidé pracovat nechtěji. (R5)

Zaměstnance bych si pečlivě vybírala a myslím, že by bylo opravdu těžké sehnat si spolehlivého člověka, který by pochopil, na čem mi záleží a v čem je ukryt úspěch podnikání. (R3)

Největši problém je najít dobré zaměstnance! Inzeráty jsou na nic. Na inzerát prijide třicet lidí a z toho třicet je $k$ ničemu. (R4)

$V$ době kdy jsem měl větši společnost, bylo opravdu složité sehnat dobrého zaměstnance. $Z$ padesáti lidí jsem měl napřiklad jen patnáct opravdu dobrých. (R/3)

Najít dobré zaměstnance je z hlavních problémů, které máme. Je to i hlavním důvodem, proč nemůžu podnik $v$ současnosti rozšiřovat - konkrétně šoféri nejsou. Je to těžká práce. (R2I)

\section{Shrnuti}

Mnoho schopností potřebných k podnikání na venkově - založeném na prírodních a kulturních zdrojích a jejich inovativním využití - jsou ve skutečnosti dovednosti životně důležité. K práci, kterou jsme $v$ této publikaci popisovali, je nezbytně nutná odpovědnost, dochvilnost, schopnost dokončit práci včas, komunikační schopnosti atd. To jsou kličové schopnosti, které činí podnikání úspěšným - kromě specifických znalostí, o produktech, trzích, nebo ekonomických zásadách. Tyto vlastnosti ale nejsou potřebné pouze pro zdárné provozování řemesla, např́klad kovářské živnosti nebo pro chov skotu a výrobu místních mléčných produktů - uplatní se v životě jako takovém. Jsou potřebné i v jiných oblastech a hrají roli za různých okolností. Pokud je pěstujeme u mladých lidí, připravíme je tím nejen k zapojení do ekonomiky, která respektuje principy udržitelnosti, ale vychováme je také, aby se účastnili dění ve své obci, městě nebo regionu. Vzdělávací program, který by inspiroval mladé lidi $\mathrm{k}$ tomu, aby se stali součástí udržitelného venkovského hospodaření, jim může tyto životně důležité dovednosti zjevně nebo „mezi řádky“ předat. Což jim pak pomůže vypořádat se s životními problémy a také se stát platným členem společnosti. Co se tedy děti nebo studenti $v$ tomto směru naučí, může přispět ke zlepšení jejich vlastního života, a posílit i vztahy v komunitě: podpořit spolupráci a účast na rozhodování.

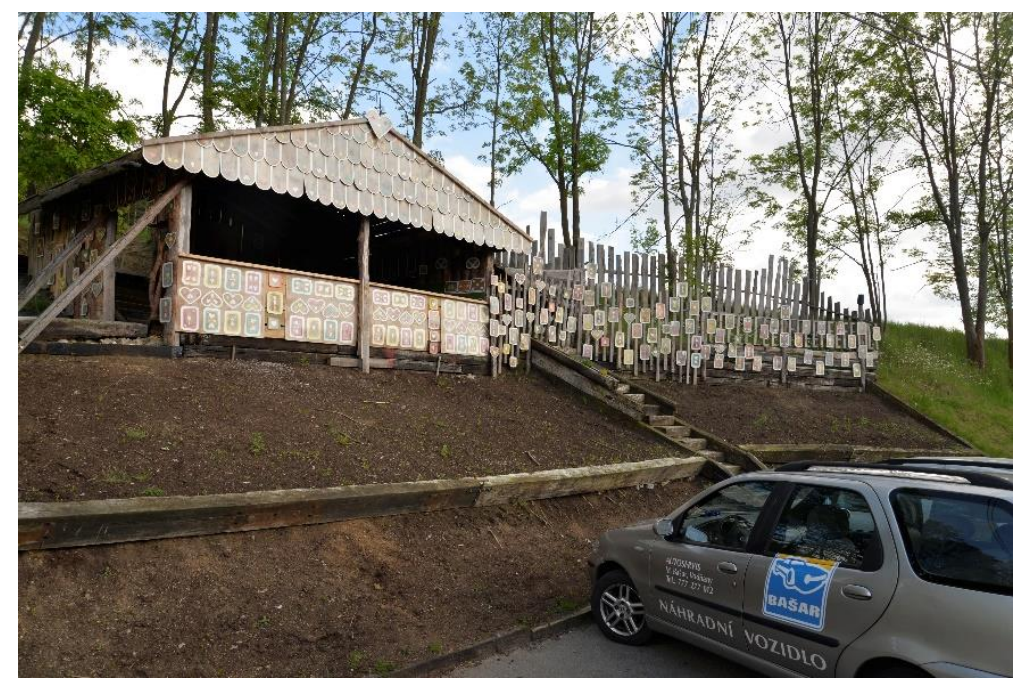




\section{Závěr}

Žijeme ve světě, který trpí četnými problémy - většinou takovými, které jsme sami způsobili svou sobeckostí, pohodlností, snahou získat nezasloužené výhody na úkor někoho (nebo něčeho) jiného. Vzdělávání se ale nemusí prrísně držet světa, jaký je; jeho prostřednictvím Ize usilovat o svět, jaký by měl být. Na rozdíl od vědy se vzdělávací cíle mohou vztahovat nejen $\mathrm{k}$ realitě, ale také $\mathrm{k}$ ideálu. $\mathrm{Na}$ tomto ideálním půdorysu lze pak utvářet nové vztahy, pěstovat podstatné zásady, a postupně tak založit jinou, lepší společnost. Svého humanistického poslání si je vzdělání vědomo - právě zde jsou úspěšně rozvijeny idealistické vize, sem se soustřed'ují snahy sociálních reformátorů, kteří prosazují dlouhodobou představu „trvale udržitelné“ společnosti a nehledí jen na společenský vzestup podle pravidel okamžité úspěšnosti. Vzdělání tak usiluje o společnost, která by se zabývala „vážnými“ problémy, a chtěla je řešit s ohledem na každého jednotlivce, jenž by se pak cítil v jejím rámci svobodně a také užitečně byl by oporou svému společenství právě tak, jako toto společenství poskytuje bezpečné zázemí jemu samému. Taková společnost by měla být založena nejen na rozumné a efektivní správě, která reguluje konkurenční prostredí. Měla by vycházet z ekonomiky, která se vrací k původnímu smyslu tohoto slova - péči o domov (oikos) - a vytváří tak základní hodnoty, pečuje o ně v dlouhodobém časovém horizontu. Bez tohoto základu postrádá kolektivní lidské snažení smysl. A bez „,autentického“ vztahu k původním zdrojům, postupům, procesům a jejich výsledkům zase tyto základní hodnoty nemohou vznikat. Abychom tento bezprostřední vztah ke skutečnosti, který se potvrzuje prací, neztratili, je třeba $\mathrm{k}$ jeho zachování přizvat i vzdělávací systém. Tato publikace má být malým př́ispěvkem do debaty na toto téma.

\section{Podnikatelé, kterých jsme se ptali (v abecedním pořádku)}

O tom, čemu poctivé podnikání učí a co mu chybí ( $v$,lidských zdrojích“), se dozvíme též z rozhovorů s drobnými podnikateli, z nichž jsme čerpali inspiraci. Niže uvádíme jejich kompletní seznam; podrobný popis jejich činnosti lze nalézt na www.enviwiki.cz (Portál podnikání, kapitola Příklady drobných udržitelných podniků na venkově).

- Mikuláš Bilík se specializuje na zakázkovou výrobu ze dřeva - kuchyňské linky, nábytek, vestavěné skříně, schody, vrata a ploty. Dále vyrábí i zahradní domky, pergoly, přístřešky, pískoviště, záhonové obruby a pokládá dřevěné a plovoucí podlahy včetně palubkových. Tím jeho výčet činností ovšem ani zdaleka nekončí. V truhlářství nabízí i služby spojené se stavebně truhlářskou výrobou, počínaje výrobou interiérového vybavení od podlah přes veškeré zařízení nábytek až po dřevěné obklady, schodiště atd.

- Pan Václav Boška je zakladatelem rodinného zahradnictví Střítež Boškovi, které se nachází v malé jihočeské obci Střítež nedaleko Strakonic. Prodejem sazenic a květin se rodina zabývá již od roku 1983 a těší se tak nejen z dlouhodobé tradice prodeje vysoce kvalitních zahradnických produktů, ale zejména z početné řady spokojených a stále se vracejících zákazníků. Areál zahradnictví, který se neustále rozšiřuje, nabízí svým návštěvníkům nejen možnost koupě široké škály rostlinných druhů, ale i zábavu pro děti v podobě zviŕrecí zoo a odpočinek a rekreaci pro dospělé. Boškovi se tímto neustálým vylepšováním snaží, aby jejich areál byl vnímán nejen jako prodejní místo, ale jako zajímavá turistická destinace, do které se zákazníci budou neustále a rádi vracet.

- Marcela Cibulková je provozovatelkou svatebního studia Elliter, který se nachází v jihočeské obci Blatná. Paní Cibulková v tomto vysoce kreativním oboru podniká již od 2010 a svým klientům nabízí nejen možnost koupě a prodeje svatebních a plesových šatů, ale i úplný servis při organizaci svateb (od A po Z). $V$ jejím kamenném obchodě si navíc zákazníci mohou zakoupit či nechat ušít módní doplňky a vkusné dárkové předměty pro nejrůzněšši přiležitosti. Vysoká kvalita služeb a maximální vstřícnost k zákazníkovi jsou ve svatebním salónu neodmyslitelným 
standardem, který tomuto studiu vytváří tu správnou reputaci a zvyšuje každoročně objem zakázek.

- Ekochov, s.r.o. je malou rodinou společností nacházející se v jižních Čechách na Šumavě. Podnik se z hlediska obchodu zaměřuje na dva základní směry. Tím prvním je chov masného skotu a následný prodej hovězího masa $v$ biokvalitě. Druhým směrem je agroturistika a $s$ ní spojený provoz penzionu, restaurace, ustájení koní a výcvik jezdců a dále doplňková agroturistika v podobě chovu koz a ovcí. $\vee$ současnosti vede podnik nejstarší dcera pana Daňka, Terezie Daňková. Jejím cílem je podnik nejen stabilizovat a v budoucnosti rozšiřrit, ale hlavně podnikat tak, aby byl člověk hrdý na to, co za sebou $v$ životě nechává.

- CHANA - DW, s. r. o. Jméno Dluahoweských patří rodině s dlouhou historií. Pan baron Václav Dlauhoweský z Dlouhévsi je potomkem starého jihočeského rytířského rodu, který odnepaměti měl úzký vztah $k$ půdě, zemědělství a českým tradicím. Po roce 1948 byl jeho rodině majetek zabaven a navrácen zpět $v$ restituci až $v$ roce 1990. $\vee$ té době byl pan Václav Dlauhoweský postaven před rozhodnutí zda vrácený majetek pronajímat, nebo se sám pustit do zemědělské činnosti a navázat tak na činnost svých předků. At' už k rozhodnutí přispěla rodinná tradice, či obchodní duch, pan Dlauhoweský opustil svůj dosavadní život veterináře a stal se zemědělským podnikatelem. Se svou rodinou se $v$ současnosti specializuje na zemědělskou a lesnickou prvovýrobu, hospodaří na vodních plochách a v malé šumavské obci Kraselov provozují penzion.

- Paní Ivana Domorázková provozuje malou vesnickou hospůdku, kde kromě běžné pohostinské činnosti organizuje i různé společenské akce jako jsou plesy, oslavy narozenin a komunitní sešlosti. Své podnikání provozuje od roku 2005, vždy se však jednalo o přidružené podnikání k její hlavní pracovní činnosti. Do obce Drachkov jí na začátku podnikání přivedla náhoda. Za ta léta, si však $k$ obci vypěstovala velmi pozitivní vztah a sama se dobrovolně podílí na mnoha obecních akcích a událostech.

- Paní Věra Englichová se již roky věnuje umělecké tvorbě a její kreativita zasahuje snad do všech uměleckých oblastí. Největšího ocenění a získání regionální značky, však získala výrobou a prodejem unikátních skleněných šperků a předmětů. Dále vlastním nákladem vydala kuchařku zaměřenou na dietu bez sacharidů. $K$ tomu všemu paní Englichová učí na střední škole a okrajově dělá kurátorku výstav $v$ uměleckých galeriích $v$ Písku. Jejím koníčkem je i známý patchwork.

- Paní Dagmar Hálová se věnuje výrobě skleněných miniatur více než deset let. Nad sklářským plynovým kahanem dává tvar a podobu skleněným tyčinkám. Z její dílny vychází nádherné miniatury $v$ nepřeberných druzích, jako jsou rozličná zviŕrátka, postavičky lidí, dekorace s velikonočním či vánočním motivem, betlémové figurky, kytičky a mnoho dalších. Paní Hálová také připravuje komponenty pro sklárnu pana Vlasáka z Bělčic, který vyrábí historické sklo a vytváŕí skleněné paličky pro Sedlickou krajku. V sortimentu paní Hálové najdeme výrobky s motivem úzce regionálním (zdroj. www.regionalni-znacky.cz). Další specializací paní Halové je restaurování památek nekulturní povahy. Se svým manželem se této činnosti věnují mnoho let.

- Společnost Prima Agri PT je zaměřena na zemědělskou výrobu. Hospodaří v podhůř́i Šumavy (okolo města Prachatice) na pozemcích s výměrou cca 1350 ha zemědělské půdy. Obhospodařované pozemky mají nadmořskou výšku 450 až $800 \mathrm{~m}$ a leží v 21 katastrech. Rostlinná výroba je zaměřena préedevším na výrobu krmiva pro skot a to jak objemné píce, tak jadrných krmiv; přebytky se prodávají. Důležitou součástí rostlinné výroby je údržba trvalých travních porostů. Jako tržní plodiny je pěstována řepka a částečně kukuřice. $V$ rámci živočišné výroby je nosným programem společnosti chov holštýnských krav a produkce mléka, chov masného skotu (Limousine) a jeho kř́ženců. Dále společnost poskytuje služby v rámci zemědělské výroby - doprava, polní práce, práce na loukách a pastvinách, prodej obilí, apod. Statutárním orgánem podniku je pan Ing. František Hodina. 
- Pekařství a cukrářství Kodádek, s.r.o. je menší společností provozující pekárnu a cukrárnu $v$ Jihočeských Vodňanech. Výroba se zaměřuje jak na pečivo, tak i cukrářskou výrobu v podobě zákusků, a dortů. Majitel společnosti, pan Václav Kodádek, je navíc autorem známého „Vodňanského kapra“ - tedy výrobku, který reprezentuje město Vodňany a který je oceněn jihočeskou regionální značkou.

- Kadeřnictví a holičství Strakonice, paní Martínková.

- Paní Pichliková je úspěšnou chovatelkou koní plemene Shagya Araba a to již od roku 1992. V jihočeských Cehnicích, kde je její hospodářství umístěna, chová koně vysoké kvality vhodné pro chov, sport i rekreaci a zároveň již 30 let neúnavně pracuje na propagaci a zviditelnění koní tohoto plemene jakožto užitkového koně pro všestranné využití. Výsledky její dobré práce jsou viditelné na Národních plemenných přehlídkách a četných sportovních soutěží (jak v ČR, tak v Evropě), kde se její odchovanci umist'ují téměř pravidelně na předních příčkách. Zároveň je zakladatelskou jezdeckého vytrvalostního klubu, ve kterém vede mládež k lásce ke koním a $\mathrm{k}$ jezdeckému sportu.

- Pan Miloslav Poleno se věnuje veškerým drobným stavebním a montážním pracím včetně podkladů, pokládání dlažeb a rekonstrukcí. Své podnikání má založeno na osobním a vřelém vztahu $\mathrm{k}$ zákazníkům. Dále si zakládá na kvalitě a vždy perfektně odvedené práci.

- Společnost Sedlická krajka, o.p.s. navazuje svou činností na 450-ti letou tradici výroby ručně paličkované krajky v Sedlici. Tyto výrobky se jak v minulosti, tak v současnosti těší velké oblibě a to nejen díky unikátním vzorům a kvalitě, ale i nevšednosti a tradici. Díky činnosti obce byla v Sedlici otevřena reprezentační prodejna, kde je možné zakoupit jak hotové výrobky, tak i veškeré pomůcky potřebné $k$ paličkování krajky. Společnost se dále věnuje výuce paličkování a pořádá jak kurzy pro začátečníky a pokročilé - děti i dospělé. Jednou z dalších významných činností společnosti patři i sběr a archivace starých vzorů krajek a rekonstrukce zapomenutých, či poškozených vzorů (paní Srbová - paní ředitelka Sedlické krajky).

- Pan Špatný, Farma KOFA je jednou z první ekologických farem založených v ČR. Nachází se $v$ malebné krajině jihočeského kraje a nabízí návštěvníkům nejen lahodné kozí výrobky, ale i pobyt na samotné farmě, vyjižd'ky na koních, nebo i netradiční možnost vyzkoušení hospodářských prací spojených s chodem farmy.

- Michal Tesař se zabývá zakázkovou výrobou zámečnických a kovaných výrobků jako jsou brány, zábradlí, kliky a další umělecké předměty ze železa. Dále se živí kováním a ortopedickým podkováním koní. Podnikat začal pan Tesař v roce 2000 a jeho zaměření bylo již od počátku zcela jasné. Kovářské řemeslo se totiž v rodině Tesařů dědí a tak i vyučení a následná profesní praxe byla pro pana Tesaře jasnou volbou. Pracovním cílem pana Tesaře je a byl spokojený zákazník. Proto se vždy snaží o co největši kvalitu vyrobených produktů a nepoužívá kovářské polotovary, které dle jeho názoru nejsou součástí dobré kovářské a podkovářské praxe. $V$ současnosti se pan Tesař stará o koně ve více jak 340 stájích a má nepřeberné množství další klientely se zájmem o jeho kovářské služby.

- Jiří Toncar s manželkou jsou vlastníky zemědělské farmy v jižních Čechách na samém prahu Šumavy. Zemědělské činnosti se zaměřením na chov masného dobytka se společně začali věnovat již po revoluci. Jejich býci dosahuji nejlepších masných hodnot a jsou prvotřídním zbožím zejména pro německou klientelu. $V$ současnosti se rodina Toncarů stará o téměř II0 hlavé stádo plemene Angus.

- Farma Jiřího Tyšera se nachází v malé jihočeské vesnici jménem Paračov. Toto malebné prostředí, téměř na hranici Šumavského pohoří je zdrojem čistého vzduchu, krásné krajiny a št’avnatých pastvin. Chovu mléčného skotu - hlavní specializací farmy - se tu proto daří. Paračov je navíc rodnou vískou rodiny Tyšerů od nepaměti a i jejich zemědělská tradice je s Paračovem úzce svázána. Pan Tyšer je hybnou silou celého podnikání, i když uznává, že s farmou pomáhají všichni členi rodiny. Pan Tyšer se mimo mléčné produkce věnuje okrajově pěstování a prodeji 
obilí a poskytuje služby v zemědělství jakou je např. výroba sena pro ostatní zemědělské subjekty. Velký př́ijem tvoří samozřejmě i finanční přispěvky z dotací.

- Cukrářská výrobna Štěkeň je výrobnou s mnoholetou tradicí. Vyrábí se zde veškerá měkká cukrařina od kynutých koláčů na svatby, až po dorty, věnečky či větrníky. Podnik své výrobky rozváží do téměř 20 provozoven v okolí. Zahrnuje tak Písecký, Volyňský a Strakonický region. Pan Vokroj vždy dbá jak na kvalitu, tak i na moderní trendy a přání zákazníků. Dorty, které si v dílně může zákazník objednat, jsou ukázkou té nejpečlivější výroby a cukrářského umění. $V$ nabídce jich má výrobna přes 60.

- Malá dopravní společnost v majetku Otty Zámečníka se nachází v jihočeských Česticích, nedaleko Volyně. Tato progresivně se vyvíjející firma diversifikuje své aktivity nejen na mezinárodní a vnitrostátní kamionovou dopravu a spedici, ale překvapivě se zaměřuje i okrajově na lesnictví a zemědělství. Společnost funguje již od roku 1995, kdy byla založena panem Ottou Zámečníkem starším. V současnosti společnost vede syn pana Zámečníka, pan Otta Zámečník mladší.

\section{Literatura}

Boyle, D. (2006). Authenticity. In Interdisciplinary Yearbook of Business Ethics (Roč. I2I, s. |2I-I28). Peter Lang Publishing Group in association with GSE Research

Enviwiki (2017). Udržitelné podnikání - př́iklady firem (kategorie). COŽP UK. Dostupné na http://enviwiki.czl

Evans Rhys, F. Papageorgiou (eds) (2007). Lifelong Learning and Sustainable Rural Development in Europe. (Editor and Plenary Chapter). Euracademy, Athens. http://www.euracademy.org/images/5thguide_print_web.pdf

Gilmore, J. H., \& Pine, B. J. (2007). Authenticity: What consumers really want. Harvard Business Press.

Padilla, Emilio. (2002) "Intergenerational equity and sustainability” Ecological Economics 4I 69-83.

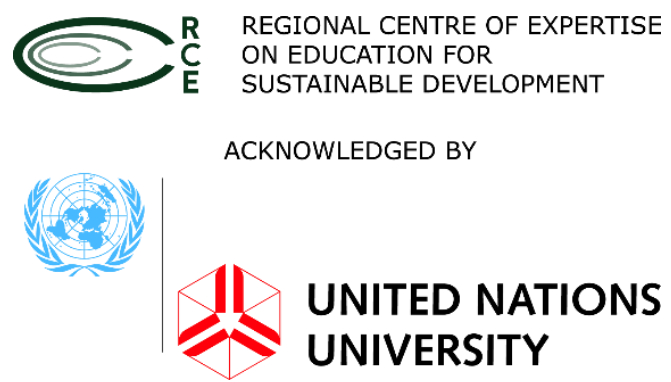

